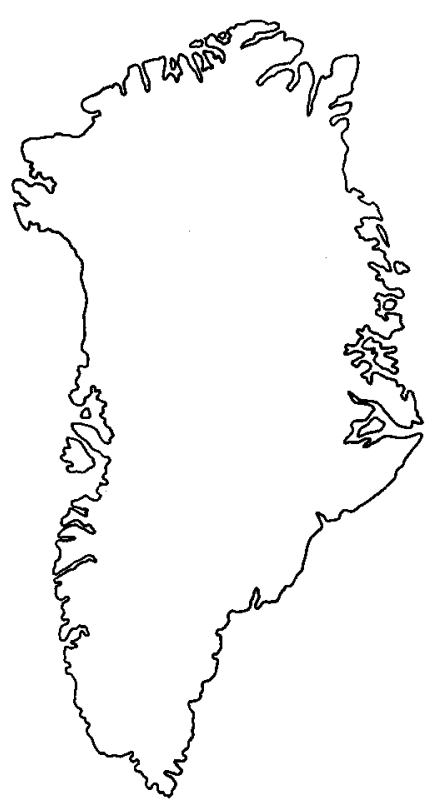

\title{
Biostratigraphic reconnaissance in the Lower Palaeozoic of western North Greenland
}

\author{
Peter R. Dawes and John S. Peel
}

\begin{abstract}
Sections and fossil collections resulting from activities under Operation Grant Land 1965-66 in the Hall Land - Wulff Land region of western North Greenland are briefly discussed. Strongly tectonised Lower Cambrian to Silurian strata are present in the northern part of the area in association with the Wulff Land anticline and the Nyeboe Land fault zone. To the south, platform and deep-water trough sequences are generally little disturbed and strata range in age from Middle Ordovician to Late Silurian (Pridoli). Most stratigraphic units can be accommodated in stratigraphic schemes established in Washington Land, to the west, or Peary Land, to the east.
\end{abstract}

P. R. D. \& J. S. P., Grønlands Geologiske Unders $\emptyset$ gelse, Øster Voldgade 10, DK-1350 København K, Danmark.

This paper presents stratigraphic and faunal notes on the Lower Palaeozoic sequence of the Hall Land - Wulff Land region of western North Greenland examined during Operation Grant Land 1965-66 (fig. 1; see Dawes, this report). Summation of this biostratigraphic information was stimulated by the recent completion of several palaeontological papers based on material collected under Operation Grant Land (Armstrong \& Dorning, this report; Lane, this report; Peel, this report; Peel \& Larsen, this report) and is intended to provide a brief stratigraphic framework to the systematic descriptions.

Several localities initially studied during 1965-66 have subsequently been revisited with the result that more detailed geological data are now available from parts of the region. The present account emphasises those areas which have remained unvisited during the last two decades, although the existence of more recent work is noted where appropriate.

GGU's field work in North Greenland since the 1960s has been concentrated in Washington Land (1975-77), to the west, and Peary Land (1974, 1978-80), to the east (fig. 2). Schemes of stratigraphic nomenclature have been introduced or are under introduction in both areas and many of the rock units described here can undoubtedly be referred to units within these schemes. Correlations are suggested where possible in the following text, but current systematic geological investigations in the region by GGU make more detailed stratigraphic discussion inappropriate.

Furthermore, on account of GGU's present field campaign, no attempt is made to present a complete summary of the stratigraphic data collected in 1965-66. Most of the field work was concentrated in the north coast region, on the variably deformed, mainly Silurian, deep- 


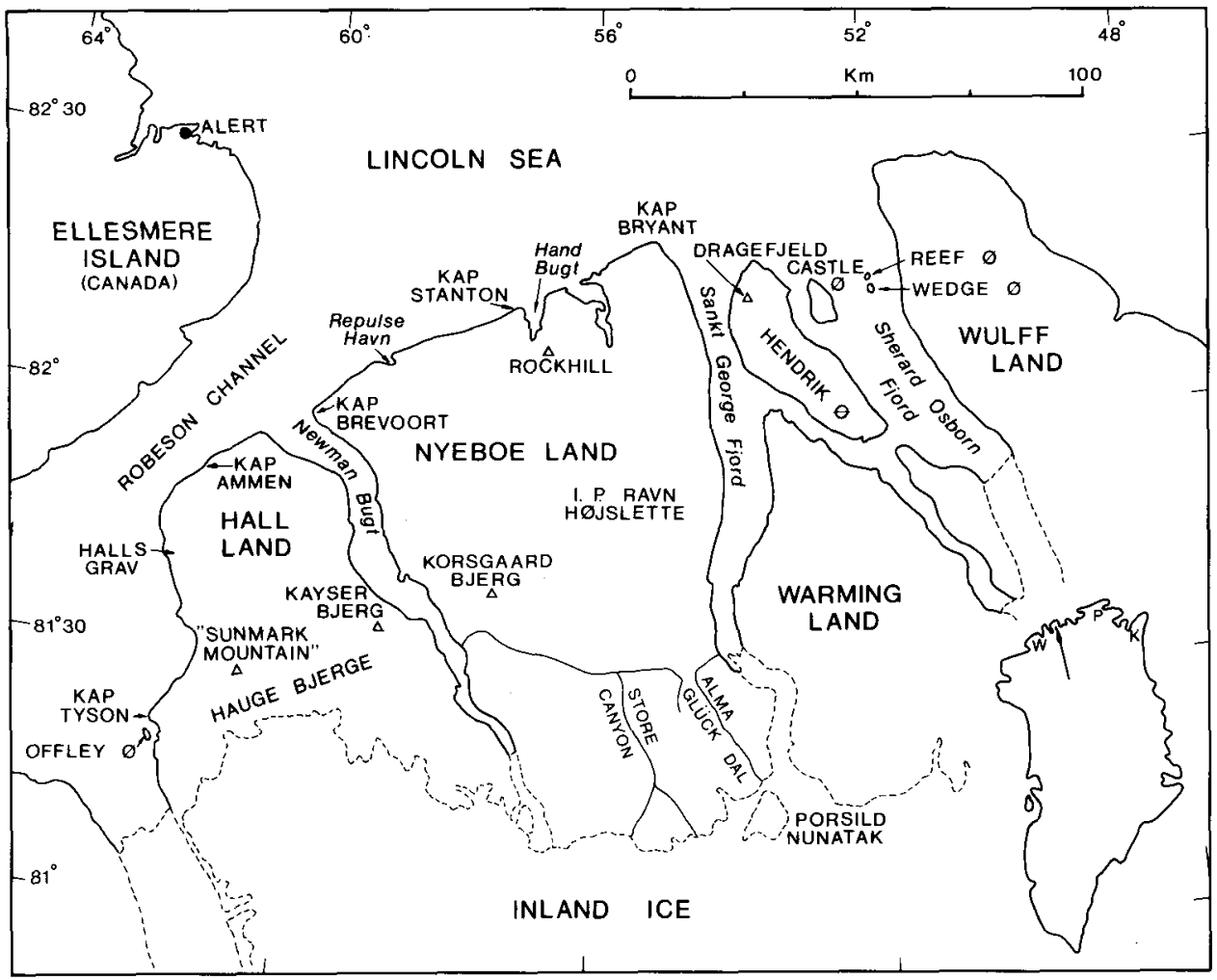

Fig. 1. Location map showing the area in western North Greenland studied during Operation Grant Land, 1965-66. Inset map: $\mathbf{W}=$ Washington Land, $\mathrm{P}=$ Peary Land, $\mathrm{K}=$ Kronprins Christian Land.

water trough sequences; strata that are poorly fossiliferous. Description of sections is restricted to those from which fossil collections were made, and the paper serves to locate the collections in the stratigraphic framework (fig. 3 ). The majority of sections are from the Ordovician-Silurian terrain of the tectonically simple, southern platform region, although several sections begin in platform carbonate strata and terminate in overlying deep-water clastics of the expanding clastic trough. Fossils indicate a range in age from late Middle Ordovician in unit 14A at Store Canyon (fig. 3) to latest Silurian (Pridoli) at Halls Grav (section 2, fig. 3). Several recent papers have discussed the possibility of Devonian strata being preserved in the Halls Grav area, but the issue is undecided (see Armstrong \& Dorning, this report). The strongly tectonised Cambrian-Silurian sequence of the northern coast region is briefly described in a separate section.

\section{Geological setting}

The coastal region of North Greenland preserves the southern margin of the Franklinian geosyncline which contains Proterozoic-Palaeozoic strata and extends far to the west across 


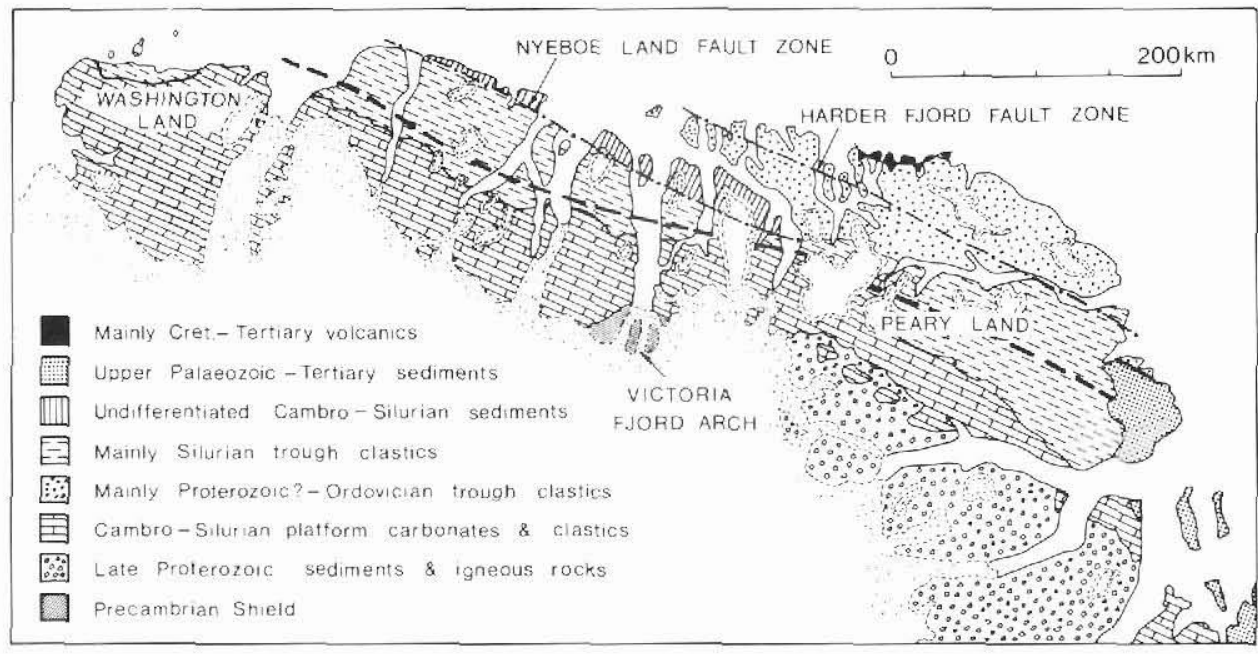

Fig. 2. Geological map of North Greenland (from Dawes, 1984). Heavy dashed line indicates southern limit of North Greenland fold belt.

Arctic Canada. In western North Greenland this linear, east-west trending sedimentary basin is composed of two geological terrains: in the south a shallow-water, mainly carbonate, platform with an exposed contact with the Precambrian Shield adjacent to the Inland Ice in the Victoria Fjord arch (fig. 2), and to the north a deep-water clastic trough. The northern part of the trough now constitutes the deformed and slightly metamorphosed North Greenland fold belt that was affected by mid-Palaeozoic (Devonian-Carboniferous) and Cenozoic (Tertiary) orogenesis.

The study region contains a Cambrian to Silurian sequence extending from the carbonates of the platform and slope, with major Silurian carbonate mound developments, to the clastic deposits of the trough. Facies changes between platform, slope and trough strata can be complex; steeply inclined, abrupt boundaries between reef carbonates, off-reefal shales and trough clastics are common. The platform-trough boundary was not a static feature throughout the Lower Palaeozoic and the trough axis shifted southwards in the later stages of its sedimentary history. Thus, in northern Hall Land, for example, Ordovician and Lower Silurian platform carbonates are overlain by Lower Silurian deep-water clastic rocks (fig. 3, section 1), while to the south a younger Silurian deep-water sequence overlaps onto the Silurian carbonate mounds and carbonate platform terrain (fig. 3, section 5).

Structurally, the region is relatively simple. Cambro-Silurian homoclinal strata in the south have a shallow northerly dip of a few degrees, so that the youngest part of the sequence outcrops in a broad belt throughout the central part of the region (fig. 2). The margin of the North Greenland fold belt is situated in this region; it is autochthonous, and deformation intensity increases northwards towards the outer coast. Several prominent eastwest trending structures occur in the fold belt; two of these, the Wulff Land anticline and the Nyeboe Land fault zone, structurally elevate platform-slope strata as old as Cambrian. 

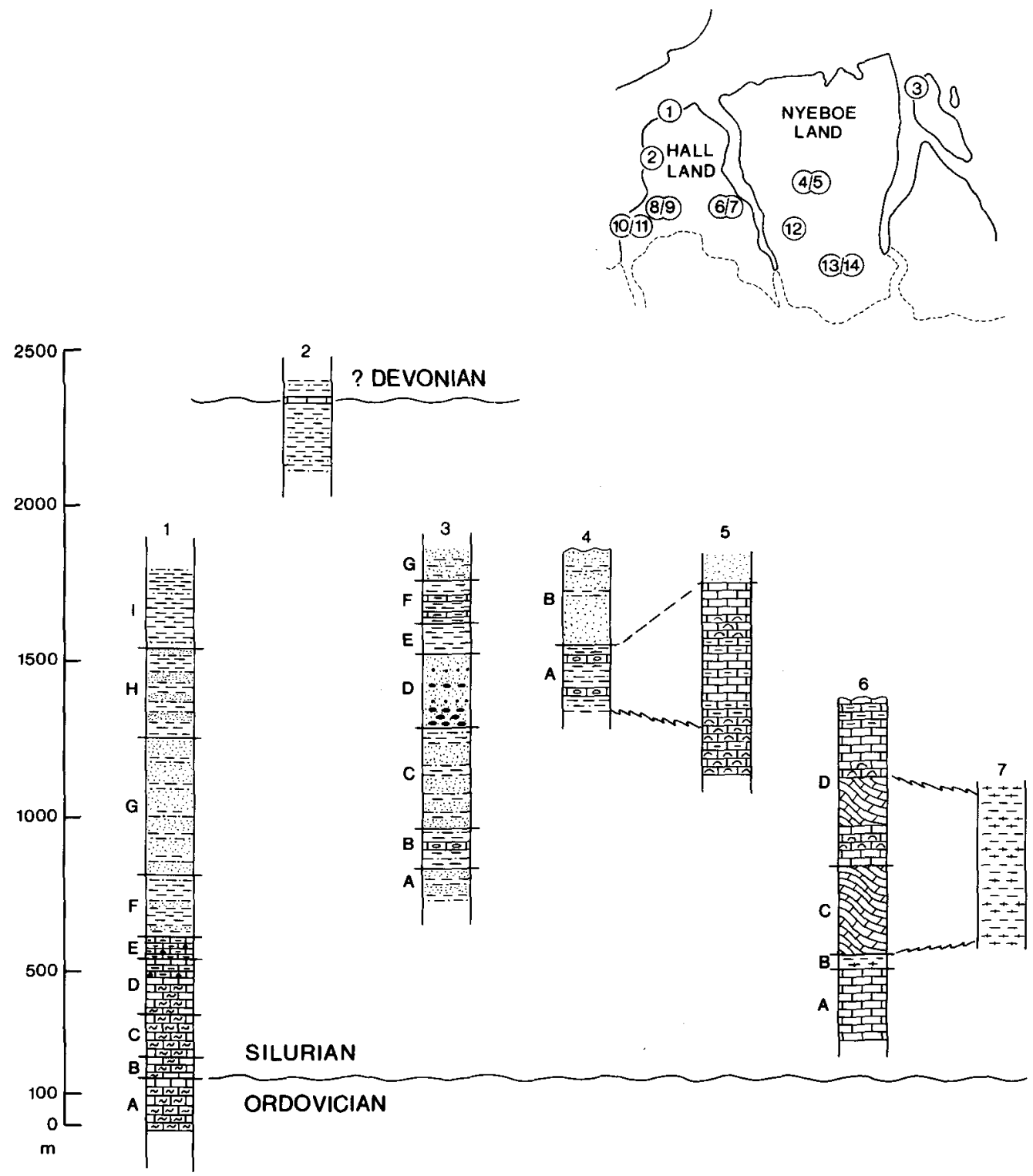

Fig. 3. Stratigraphic chart of Ordovician-Silurian (and ?Devonian) sections studied in 1965-66 and from which fossils were collected. Sections are numbered and located on the inset map; units are designated by letters and described in the text. 
Limestone, dolomitic limestone

通融 Argillaceous limestone

BIy Main carbonate build-up

高到 Limestone breccia, conglomerate

窝武 Biohermal limestone

Limestone, mottied / cherty
Platy limestone

$=-$ Shale

Siltstone

Sandstone

Pebbly sandstone

--- Chert-pebble conglomerate
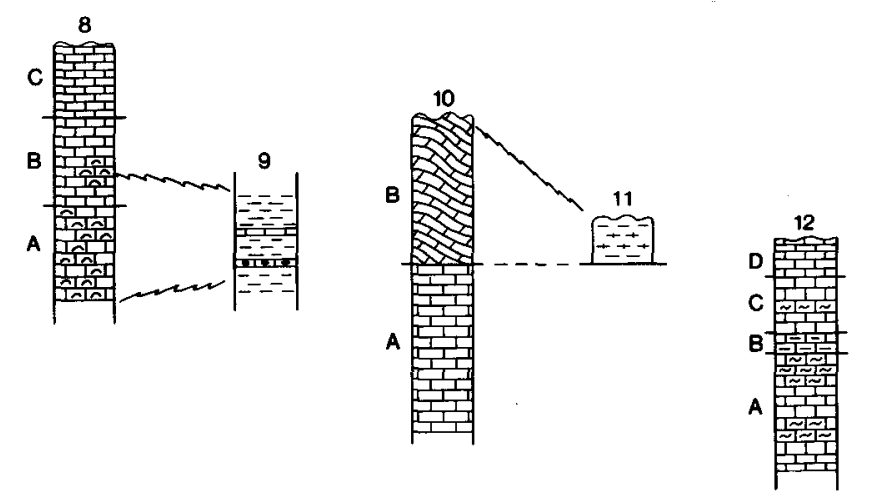

13

E

D

0 II

敦

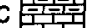

B

A
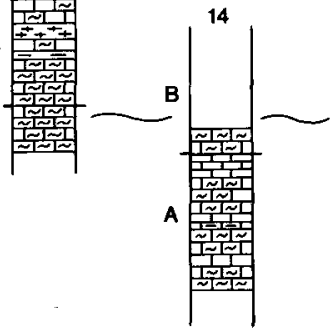


\section{Cambrian to Silurian of the northern coast region}

The Wulff Land anticline and the Nyeboe Land fault zone are major, coast-parallel structures that have had profound effects on the regional disposition of the rock units in northern Nyeboe Land and Wulff Land (Dawes, 1982, fig. 4). The strata of northern Nyeboe Land are severely folded and faulted, and weakly metamorphosed. Structural complexities have not been studied in detail and the full stratigraphic succession is unknown. Cambrian and Silurian sediments are identified and the presence of Ordovician strata is to be expected. Cambrian strata were recorded north of the Hand Bugt fault in northern Nyeboe Land and northern Wulff Land; Silurian rocks have been identified south of the Hand Bugt fault.

The results of a brief visit in 1966 to northern Wulff Land were summarised by Dawes (1976). The sequence has subsequently been revisited by GGU geologists during 1979 (Dawes, 1982, pp. 181-182). Pale dolomites $(350 \mathrm{~m})$ are tentatively correlated with the Portfjeld Formation of Peary Land of Early Cambrian age (Peel, 1982; Peel \& Christie, 1982), while underlying dark clastics and resedimented carbonates (at least $400 \mathrm{~m}$ ) may correlate with part of the Kennedy Channel Formation of Ellesmere Island. Overlying clastic sediments may be correlated with the Lower Cambrian Buen Formation of Peary Land and younger strata. A full Cambrian platform sequence is present in southern Wulff Land and adjacent Warming Land (Hurst \& Peel, 1979; Peel, 1980).

Cambrian strata occurring north of the Hand Bugt fault in Nyeboe Land were principally examined at localities south and south-west of Kap Bryant and south of Kap Stanton. Two main rock groups were recognised; a varied carbonate sequence, at least $600 \mathrm{~m}$ thick, consisting of limestone, breccio-conglomerates and shales, and a clastic sequence, at least $300 \mathrm{~m}$ in thickness, composed mainly of sandstones, arkoses and slates (fig. 4). Fossils of Early and Middle Cambrian age are known from the carbonate sequence (Poulsen, 1969; Peel, 1974, 1979; Peel \& Larsen, this report), but an overlying pale weathering sequence characterised by carbonate breccias and conglomerates may reach into the Ordovician. The lower carbonate sequence in Nyeboe Land may be partly equivalent to the Lower to Middle Cambrian Brønlund Fjord Group of Peary Land. The Brønlund Fjord Group is succeeded by generally pale weathering sandstones and carbonates with prominent debris flows of the Tavsens Iskappe Group (Middle Cambrian - Early Ordovician age; Ineson \& Peel, 1980; Peel, 1982) which could be a correlative of the upper pale sequence of Nyeboe Land.

The dark limestones and shales south of Kap Bryant have yielded a fauna of late Early Cambrian age. Trilobites in GGU 83337-8 include Serrodiscus bellimarginatus, Calodiscus and pygidia and fragments of an olenellid (Peel, 1974, 1979); associated fossils include Pelagiella, Latouchella, Chancelloria, the phosphatic 'button' Hadimopanella apicata (see Peel \& Larsen, this report) and fragmentary inarticulate brachiopods. A similar fauna, including $S$. bellimarginatus and $H$. apicata, is known from the Early Cambrian of southern Spitsbergen (Major \& Winsnes, 1955; Wrona, 1982), while Serrodiscus is also known from the Lower Cambrian Buen Formation of Peary Land (Palmer \& Peel, 1979).

Dark limestones, shales and calcareous sandstones from south-west of Kap Bryant yielded fragments of olenellid(?) trilobites and a possible hyolithid, suggestive of an Early Cambrian age (GGU 83345).

South of Kap Stanton, bituminous limestones and shales yielded inarticulate brachiopods, trilobites and a possible stenothecoidid of Middle Cambrian age (GGU 83382-92). The trilobites have been described by Poulsen (1969) who recognised associations indicative of 


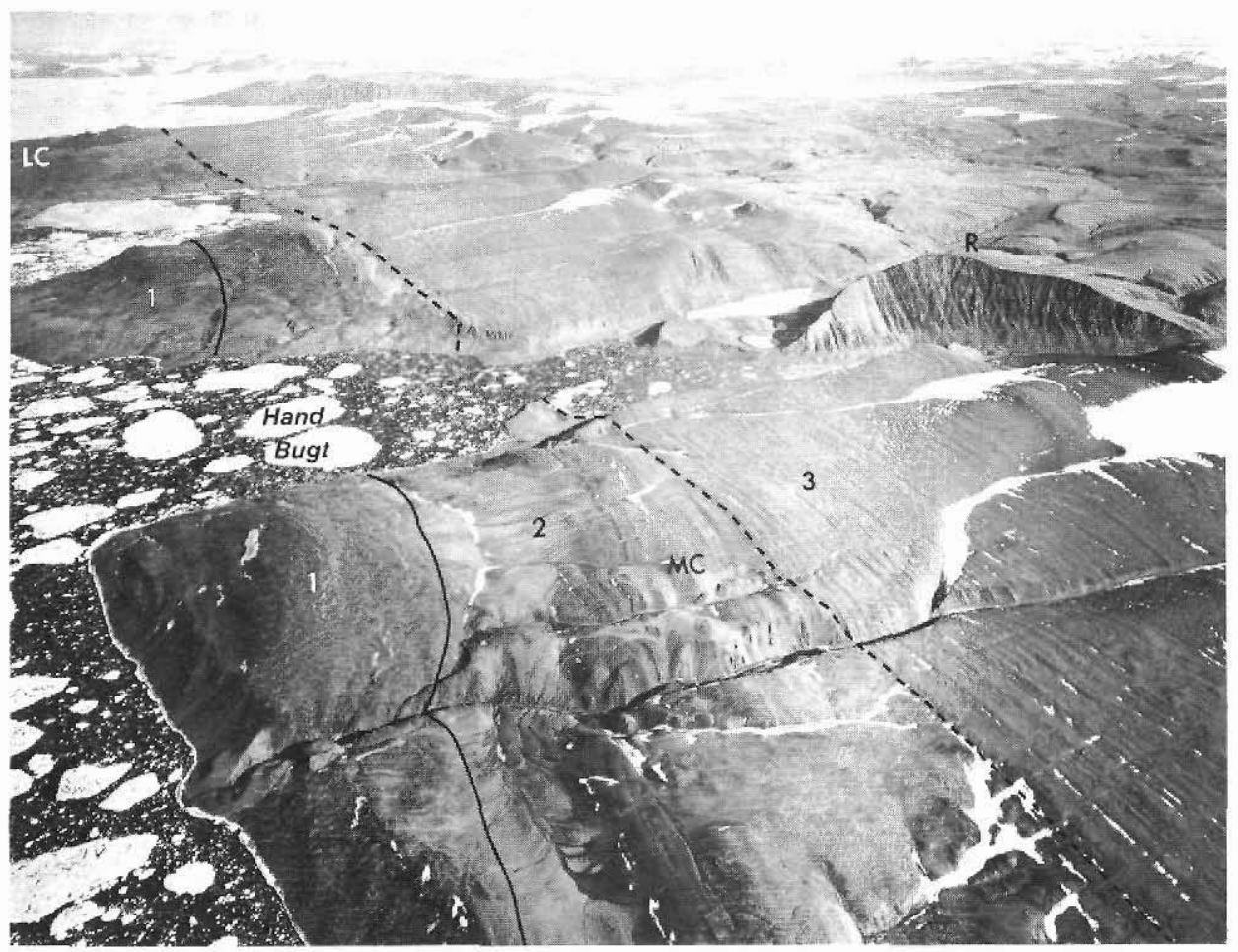

Fig. 4. The northern coast of Nyeboe Land around Hand Bugt. View is to the east showing the Hand Bugt fault (dashed) and the linear belt of steeply-dipping Silurian turbidites south of it. $1=$ Late Cambrian? clastics, 2 = Cambrian and Ordovician carbonates and shale, 3 = Silurian clastics, mainly units $1 \mathrm{G}, \mathrm{H}$ and I. LC and MC = Lower and Middle Cambrian fossil localities. R = Rockhill. Aerial photograph $546 \mathrm{E}-\varnothing$, nr. 11577, copyright Geodætisk Institut, Denmark, published with permission A. $649 / 78$.

the zones of Ptychagnostus punctuosus and Jincella brachymetopa. Robison (1984) commented that specimens assigned by Poulsen to Ptychagnostus punctuosus itself should be re-assigned to Ptychagnostus sp. indet. and Onymagnostus; Ptychagnostus punctuosus is thus not currently known from Greenland.

Silurian strata have been identified south of the Hand Bugt fault in the varied sequence of limestones and slates that outcrops along the coastal cliffs around Repulse Havn. A sequence of pale limestones, limestone conglomerates and slates exposed west of Repulse Havn in an anticline and in apparent stratigraphic contact with clastic rocks has yielded Favosites, smooth ostracodes and crinoid debris (GGU 83395-98). This fauna is considered indicative of a Silurian age - previously, it has been described as "an indeterminate crinoidcoral fauna" of probable Ordovician age (Dawes, 1982, p.180).

The pale grey limestones and slates resemble lithologies of Early Silurian age occurring in the Kap Ammen section in northern Hall Land and a correlation is suggested with the uppermost part of the carbonate sequence (unit 1D) and/or the basal part of the mainly clastic sequence (unit $1 \mathrm{E}$ ). The presence of carbonate strata equivalent to lower parts of the 
Kap Ammen section is to be expected within the varied limestone succession outcropping around Repulse Havn.

\section{Kap Ammen, Hall Land}

The traversed section at Kap Ammen (section 1, fig. 3) is from sea-level and along the coastal cliffs on the eastern side of the valley, 'The Gap', that forms a conspicuous break in the steep cliffed coastline (fig. 5).

A lower carbonate sequence, about $550 \mathrm{~m}$ thick, is overlain by a predominantly clastic sequence, about $1300 \mathrm{~m}$ of which were traversed. An unknown, but clearly substantial thickness of clastic rocks overlies the Kap Ammen section and outcrops in Hall Land and northern Nyeboe Land. Nine unnamed units were recognised; four units (1A-1D), alternating dark and light weathering, make up the lower, massive carbonate sequence. Five wellbedded units form the upper dark weathering, mainly clastic sequence, although the lowest of these (unit 1E) represents a transitionary facies of dark platy limestones (figs 5, 6).

The division into massive carbonate and well-bedded clastic rocks was recognised by Bessels (1879). A geological sketch of the coast, showing Kap Ammen, was presented by Koch (1920, pl. 1) who later assigned the lower massive carbonate part of the succession to the Silurian Offley Island Formation and the upper clastic part to the Cape Tyson Formation (Koch, 1929; Dawes \& Haller, 1979, figs 12 \& 13). This bipartite division of the Kap Ammen section was upheld by Davies et al. $(1959$, fig. 14), Allaart $(1965,1966)$ and Dawes $(1971$, 1976); the latter author referring the upper dark weathering clastic part of the section to the Cape Rawson Group of Arctic Canada. Dawes (1982) recognised nine informal units in the Kap Ammen section. Hurst \& Surlyk (1982) examined in detail a $450 \mathrm{~m}$ thick section in the clastic sequence and referred the entire sequence to three formations of the Peary Land Group.

The carbonate sequence has remained unstudied since 1965 .

\section{Unit $1 A$}

The base of this unit is not exposed; a thickness of about $160 \mathrm{~m}$ outcrops above sea-level in the cliffs at Kap Ammen (fig. 5). The unit is composed of dark weathering, dark grey to bluish grey, mottled, fine-grained dolomitic limestone. Actinoceratid cephalopods are conspicuous on weathered bedding surfaces. Mottling intensity and pattern varies throughout the unit. In the lower part, the rock matrix is dark with a light mottling component. In the upper part, the light component in places becomes dominant and there are several beds of light grey limestone near the top.

The fauna of unit 1A (GGU 82404-42) collected from the upper $80 \mathrm{~m}$ is dominated by molluscs and corals, together with the stromatoporoid Beatricea regularis (Peel, 1975). Gastropods include Trochonema, Cymbularia(?), Liospira, Maclurites, Bucania, Lophospira(?) and an indeterminate high spired form. Kochoceras spp. are conspicuous among the cephalopods, associated with armenoceratid siphuncles. Corals include Catenipora cf. C. robusta, Paleophyllum, Favosites(?), and Paleofavosites(?). B. E. Neuman (personal communication) has identified the solitary rugosans Grewingkia, Helicelasma cf. $H$. selectum and Bighornia. The fauna as a whole is clearly Late Ordovician with many specimens resembling species known from the upper part of the Morris Bugt Group of Washington Land (Peel \& Hurst, 1980), faunas from which were described by Troedsson 
(1926, 1928). Beatricea and favositids/paleofavositids were not recorded by Troedsson from the Washington Land sequence, but the latter are well represented in more recent GGU collections.

\section{Unit $1 B$}

This unit is composed of variously mottled, pale weathering, massive, fine-grained grey limestone and dolomitic limestone. At the base a $1 \mathrm{~m}$ thick bed of crinoid debris is overlain by a black, mottled limestone bed, $2 \mathrm{~m}$ thick. A $15-20 \mathrm{~m}$ sequence of dark, strongly mottled dolomitic limestone in the middle of the unit is similar to the lower part of unit $1 \mathrm{~A}$.

Fossils from the basal part of the unit (GGU 82443-55) include Huronia and other cephalopods, Paleofavosites cf. P. nodosus, Favosites and Rosenella cf. $R$. irregularis. A. J. Boucot (personal communication) has identified the brachiopod Holorhynchus, a common Late Ordovician genus known to reach into the Early Silurian. Rosenella irregularis was described by Poulsen (1941) from the Lower Silurian of Washington Land, while Huronia is known in Greenland from the upper part of the Morris Bugt Group of Washington Land, of Late Ordovician age (Troedsson, 1926).

Fossils from the middle and upper part of unit 1B (GGU 82456-64) include poorly preserved corals - Favosites, Protrochiscolithus(?), Calapoecia(?) and Palaeophyllum Rosenella and other stromatoporoids and a poorly preserved cephalopod. B. E. Neuman (personal communication) reports a species of Bighornia distinct from that recorded from unit $1 \mathrm{~A}$.

As an entity, the fauna points to the vicinity of the Ordovician-Silurian boundary, which probably lies within the unit.

\section{Unit 1C}

Unit $1 \mathrm{C}$ is composed of dark weathering, massive, variously mottled, grey to bluish grey limestone and dolomitic limestone that resembles the main lithology of unit 1A. Some beds are characterised by abundant pentamerid brachiopods.

The collection from unit 1C (GGU 82465-86) is dominated by pentameroids assigned to Virgiana by P. M. Sheehan and J. M. Hurst (personal communication) and considered to indicate a late Early Silurian age (this is the Eoconchidium of Dawes (1976) and Boucot \& Hurst (1979)). Associated fossils include species of Favosites, such as $F$. cf. F. favosus forma C of Poulsen (1941), Paleofavosites cf. P. groenlandicus, and one example each of a rugose coral, a stromatoporoid and a bellerophontacean gastropod.

\section{Unit $1 D$}

Unit 1D is composed of pale weathering, massive grey to brownish grey, variously mottled and veined limestones. The upper part is thinner bedded and contains platy limestones and calcareous slates. Two conspicuous darker beds of shales, chert and, in places, nodular limestone, occur near the top of the unit (fig. 6B). To the west of Kap Ammen, a number of carbonate build-ups occur in the upper part of the unit and at Kap Porter a large bluffforming carbonate mass is developed (Dawes \& Haller, 1979); interpreted by Hurst \& Kerr (1982) as a platform margin build-up. 


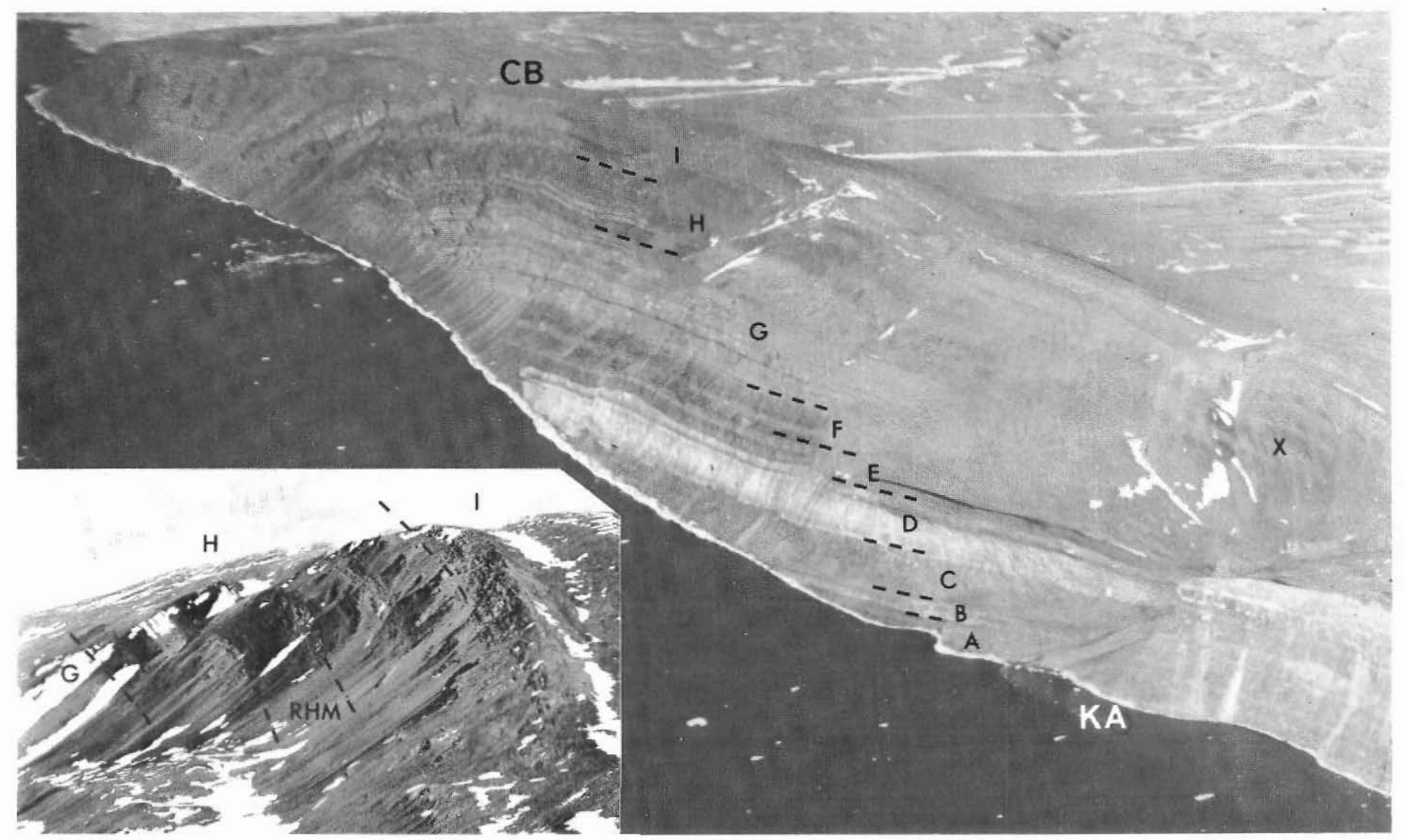

Fig. 5. Northern coast of Hall Land, west of Kap Ammen (KA) showing Ordovician - Silurian platform carbonates (section I, units A-D, Morris Bugt and Washington Land Groups) overlain by the Silurian Peary Land Group (units E-I). Chester Bjerg (CB) is at about $835 \mathrm{~m}$. Acrial photograph $546 \mathrm{~K}-\mathrm{S}$, nr. 2198, copyright Geodætisk Institut, Denmark, published with permission A.649/78. Inset: turbidite units IG, H and I, inland from Kap Ammen; located at $\mathrm{X}$ on aerial view. About $450 \mathrm{~m}$ of strata are exposed. RHM $=$ Repulse Havn Member of Hurst \& Surlyk (1982). 
Fig. 6. Ordovician - Silurian sequence at Kap Ammen, northern Hall Land showing platform carbonate units (A-D) overlain by darker platy limestones (unit E). Note change in lithology in upper part of unit D and the two prominent dark shale-chert-limestone beds. $\mathrm{A}=$ coast, east of Kap Ammen, with cliff summit at 370 $\mathrm{m} ; \mathrm{B}=$ east face of Kap Ammen, summit of cliff is at about $250 \mathrm{~m}$. For location see fig. 5 .
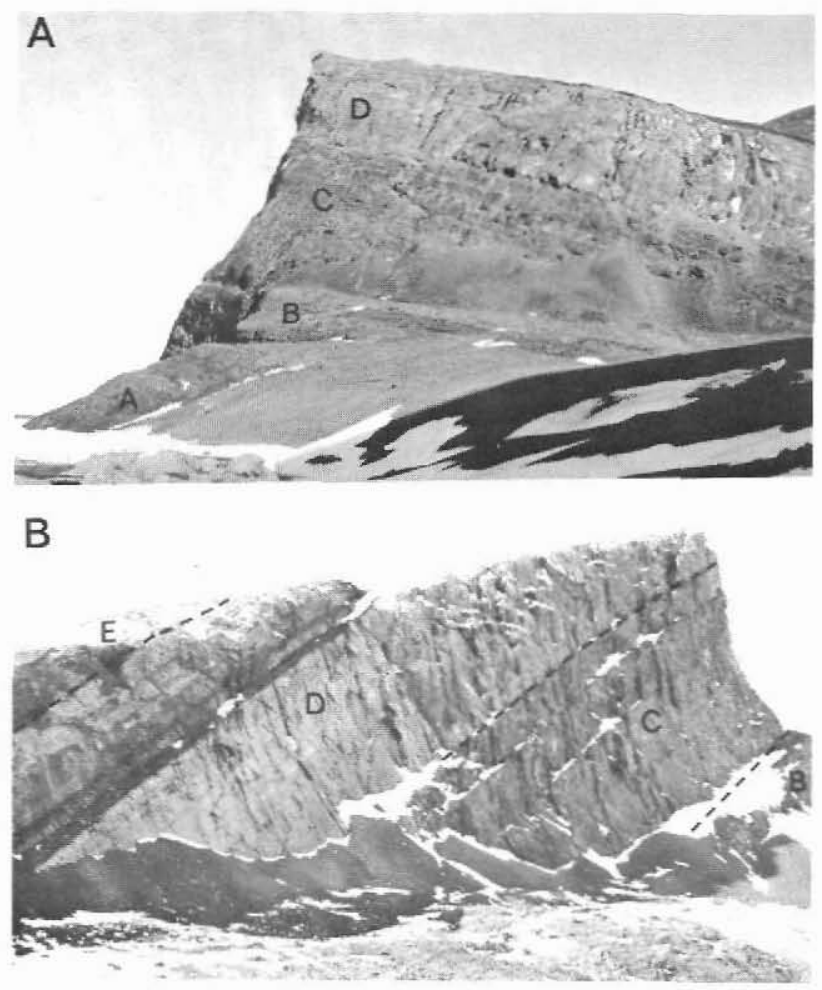

Collections from the middle of unit 1D (GGU 82487-91) contain Favosites, smooth ostracodes and a pygidium compared to Opoa adamsi by Lane, this report. Samples from the upper part of the unit (GGU 82492-7) include Favosites, nuclei of platyceratacean, subulitacean, bellerophontacean and onychochilacean gastropods, Loxonema(?), Holopea, Liospira(?), Palaeoscurria(?), Siluracmaea(?), Kionoceras, fragments of encrinurine and cheirurine trilobites and smooth ostracodes. A number of brachiopods of Coelospira-type are known from the Early Silurian and younger deposits of western North Greenland. The fauna is Silurian, probably Early Silurian.

\section{Unit $1 E$}

In the simplified bipartite subdivision of the Kap Ammen sequence employed by Dawes (1982), this unit of dark weathering, thin-bedded platy limestones, with subsidiary pale compact limestones, calcareous shales and dark cherts, was considered to be the basal transitionary member of the clastic sequence, overlying the platform carbonates described above. It was interpreted as a slope facies.

Fossils were collected from near the base of the unit (GGU 82498-503) and about $20 \mathrm{~m}$ below the top (GGU 82504-5). The lower assemblage contains Favosites, crinoids, Geisenoceras sp. and other orthocone nautiloids, the infilled body chamber of one yielding the gastropods Stylonema and Kjerulfonema(?), and the brachiopod Coelospira (J. M. 
Hurst, personal communication). Kjerulfonema was described from the Early Silurian of Norway, Britain and the U.S.A. by Peel \& Yochelson (1976) and, together with Stylonema, indicates a Silurian age. The upper assemblage contains poorly preserved corals and cephalopods.

\section{Unit $1 F$}

Unit $1 \mathrm{~F}$ is composed of dark weathering, grey to dark grey shales and calcareous slates and siltstones, with some thin beds of lighter coloured, fine-grained calcareous greywacke. No fossils are known.

\section{Unit $1 G$}

Unit $1 \mathrm{G}$ is composed of brown weathering, thin bedded, fine-grained calcareous greywacke and siltstones, with alternating dark shale beds. Occasional thin quartzite beds occur.

J. M. Hurst and F. Surlyk (personal communication) collected graptolites from this unit in 1979, identified as Monograptus priodon(?) and $M$. (M.) dubius by M. Bjerreskov indicating a Late Llandovery - Early Wenlock age (late Early Silurian - early Middle Silurian).

\section{Unit $1 H$}

This unit is composed of alternating sub-units of siltstone and fine-grained greywacke, and shales and silty mudstones (fig. 5). Hurst \& Surlyk (1982, p. 70) record Pristiograptus dubius suggesting an Early Ludlow (early Late Silurian) age.

\section{Unit 1I}

Unit $1 \mathrm{I}$ is a light brown weathering, dominantly mudstone unit composed of grey to greenish grey, laminated mudstone and shale with thin beds of siltstone and fine-grained greywacke. Unidentifiable graptolites occur near the base of the unit. Orthid brachiopods and a nuculoid bivalve are known from corresponding strata east of Kap Brevoort in northwestern Nyeboe Land (GGU 82102-4).

\section{Correlation}

The lower part of the carbonate sequence, units $1 \mathrm{~A}, 1 \mathrm{~B}$ and $1 \mathrm{C}$ can be referred to the upper part of the Morris Bugt Group, defined by Peel \& Hurst (1980) and Hurst (1980) from Washington Land. A more precise correlation with formations of this group is not attempted. Assignment of these Kap Ammen units to the Aleqatsiaq Fjord Formation is to be expected, but the sparse fauna available from the latter at its type section in Washington Land is not closely comparable to the Hall Land fauna. Unit 1D can be referred to the Washington Land Group of Hurst (1980); the lower part probably corresponding to the Petermann Halvø Formation, and the upper part, including the carbonate build-ups, a correlative of the Bessels Fjord Formation.

Hurst \& Surlyk (1982, figs 78, 82, pl. 2) referred the lower part of the clastic sequence 
Fig. 7. Shales and mudstones in section 2 , in the inland cliffs east of Halls Grav, western Hall Land. Height of cliffs is about $200 \mathrm{~m}$. This section has yielded graptolites of Pridoli (latest Silurian) age.

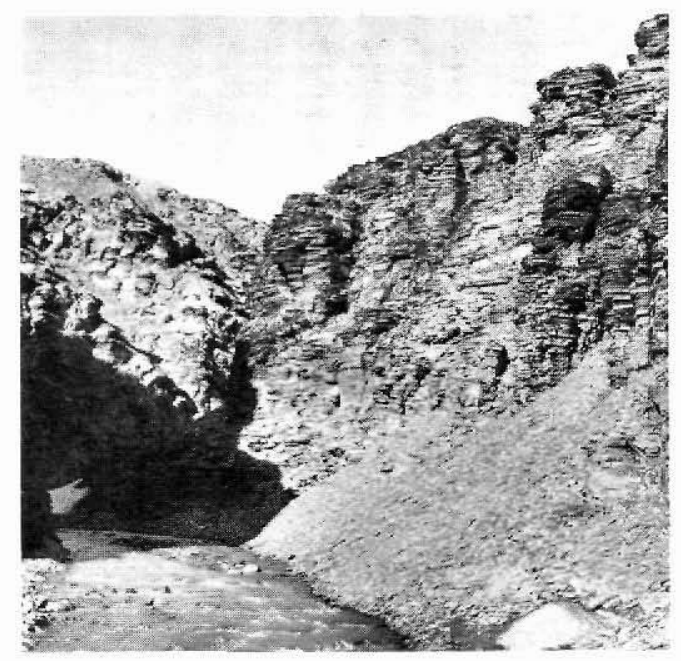

(units $1 \mathrm{E}, 1 \mathrm{~F}, 1 \mathrm{G}$ and $1 \mathrm{H}$ ) at Kap Ammen to "interfingering Lauge Koch Land Formation and Wulff Land Formation" of the Peary Land Group. However, the basal unit of platy limestones (1E) contrasts lithologically with these two formations, and it should be recognised as a distinct formation. Its dark, thin-bedded, fine-grained limestone lithology characterised by dark chert beds, resembles the redefined Cape Schuchert Formation of Hurst (1980), known from Washington Land, and unit $1 \mathrm{E}$ is provisionally referred to that formation. The unit represents a transitional facies between the underlying shelf carbonates and the deep-water trough turbidites of the Peary Land Group.

One of the shale sub-units within unit $1 \mathrm{H}$ has been referred by Hurst \& Surlyk (1982) to the Repulse Havn Member of the Wulff Land Formation (fig. 5). The uppermost unit (1I) corresponds with the Chester Bjerge Formation of these authors.

\section{Halls Grav, Hall Land}

The section is located in the inland cliffs, east and north-east of Halls Grav, western Hall Land (section 2, figs 3, 7). The strata are severely deformed, varying from shallowly dipping to inclined up to about $45^{\circ}$; small-scale folds, some of which are isoclinal, and cleavage are developed. True stratigraphical thickness is unknown, but it is estimated that at least $200 \mathrm{~m}$ of strata are exposed in the cliffs.

Located near the notable landmark of C. F. Hall's grave, the area has been visited by several expeditions and some geological observations have been made, for example Bessels $(1879$, p. 152$)$. Davis $(1876$, p. 339) reported that the inland cliffs are composed of "slaty overhanging layers of Devonic limestone".

\section{Description}

The section is composed of a brown to buff weathering, thin-bedded, monotonous sequence of grey, variously laminated mudstones, with some calcareous siltstones and platy 
limestone and occasional darker weathering beds of fine-grained greywacke. In the upper part of the cliffs, some thin beds of limestone and limestone breccia occur. One of these beds, on the eastern side of 'Observatory Bluff', is at least $1 \mathrm{~m}$ thick and highly fossiliferous.

\section{Fauna and age}

Graptolites from the lower part of the cliffs (GGU 82722-82731) were referred by W. B. N. Berry to Monograptus sp. of $\boldsymbol{M}$. transgrediens type, indicative of a Pridoli (Late Silurian), probably later Pridoli age (Berry et al., 1974). Berry also referred a single specimen to Monograptus cf. $M$. aequabilis which suggested an earliest Devonian age. The latter specimen was redetermined by $\mathrm{H}$. Jaeger as Monograptus cf. $M$. transgrediens, probably indicative of a Pridoli age (in Surlyk et al., 1980).

The limestone bed at 'Observatory Bluff' (GGU 82733-38) has yielded large quantities of small vertebrate remains (Bendix-Almgreen \& Peel, 1974; Bendix-Almgreen, 1976) after acetic acid digestion. Associated fauna includes Heliolites and bryozoans, and internal moulds of gastropods, brachiopods, cephalopods and ostracodes. R. J. Aldridge (personal communication) has provisionally referred rare conodont elements to Ozarkodina excavata, $O$. cf. $O$. confluens and Pelekysgnathus sp.

Most of the vertebrate material consists of acanthodian scales (Nostolepis, 'Gomphodus' and 'Poracanthodus'). Associated acanthodian dentigerous jaw-bones are apparently referable to Nostolepis, although tooth-whorls compare best to 'Gomphodus'. Bendix-Almgreen \& Peel (1974) and Bendix-Almgreen (1976) also recorded heterostracan plates resembling Poraspis and Oniscolepis and thelodonts. The latter have subsequently been re-examined by S. Turner (personal communication) who reports Thelodus trilobatus, Logania, Katoporus and rare Nikolivia.

Bendix-Almgreen \& Peel (1974) and Bendix-Almgreen (1976) noted the general similarity of the vertebrate fauna with Late Silurian - Early Devonian faunas from Svalbard and the United Kingdom. Provisional determination of an Early Devonian age reflected the graptolite identifications of Berry et al. (1974), which have now been revised to Pridoli (Late Silurian). S. Turner compared the thelodonts with Late Silurian (Downtonian $=$ Pridoli) assemblages from western Europe. Palynomorphs from GGU 82738 are discussed by Armstrong \& Downing in this report, but their interpreted Wenlock or Early Ludlow age fails to clarify the age relationships of these, the hitherto youngest known strata from the pre-Innuitian orogenic sequence in North Greenland.

Lane et al. (1980) described a new species of Hemiarges in a collection originally made by Lauge Koch in 1922 from Newman Bugt. The fossils were obtained from an erratic block of calcareous sandstone not unlike strata known from the Halls Grav area. Lane et al. (1980) suggested a Late Silurian (Pridoli) age for the trilobite, based on comparison with described Canadian species.

\section{Correlation}

The strata at Halls Grav have been referred by Hurst \& Surlyk (1982) to the upper part of the Chester Bjerg Formation of the Peary Land Group. The presence of limestone beds has not been recorded by these authors in the type area of the formation in northern Hall Land. 


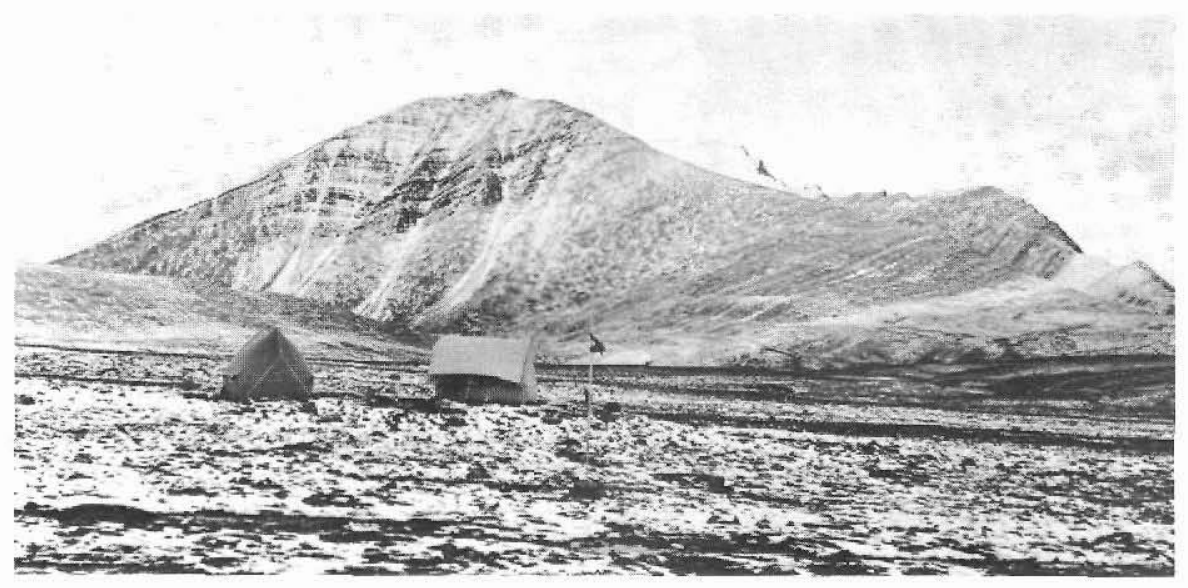

Fig. 8. View of Dragefjeld $(950 \mathrm{~m})$, northern Hendrik $\varnothing$, seen from the east showing the inclined Silurian clastic succession and site of section 3 in the river valley at the base of the mountain. The pale recessive unit forming a col on the ridge in the extreme right is unit 3B. Camp is at about $200 \mathrm{~m}$ above sea-level.

\section{Hendrik $\emptyset$}

This section (section 3, fig. 3) is located along the main north-south river valley in northern Hendrik $\varnothing$, east of Dragefjeld (fig. 8).

The section is faulted and folded and in places strata are overturned. Thicknesses shown in fig. 3 are estimates, made without thorough analysis of the structural pattern. An estimated thickness of $600 \mathrm{~m}$ outcrops and seven units were recognised in the field.

Of the early visits to Hendrik $\varnothing$, those of Beaumont (1877) and Koch (1920) are geologically noteworthy. Beaumont's mention of 'puddingstone' is the first reference to the Silurian chert-pebble conglomerate of the flysch sequence; Koch drew attention to the structural complexities of northern Hendrik $\varnothing$. Hurst \& Surlyk (1982) measured several profiles through the clastic rocks of northern Hendrik $\varnothing$ and referred the strata to three formations.

\section{Description}

The lower part of the section is composed of brown weathering fine-grained calcareous greywacke and siltstone with intercalated shale beds (unit $3 \mathrm{~A}$ ). This is in possible fault contact with a light weathering, recessive unit of calcareous siltstone and shales that contains thin, fossiliferous limestone and limestone breccia beds (unit 3B). Above this is a finegrained calcareous greywacke with some siltstone and shales (unit $3 \mathrm{C}$ ) that passes into a resistant, chert-pebble conglomerate and sandstone unit (unit 3D) - the Hendrik Conglomerate of Dawes (1966). The lowermost part of this unit is predominantly conglomerate sensu stricto, with beds of sandstone and pebbly sandstone; the upper part contains more sandstone but with frequent gradations to pebbly sandstone and conglomerate. The overlying sequence is recessive and can be divided into a lower unit (3E) of mudstone and siltstone and an upper unit $(3 \mathrm{~F})$ of black graptolitic shales with some thin dark limestone and slaty 
limestone beds. The youngest unit (3G) is composed of fine-grained calcareous greywacke, siltstone and shale, similar in lithology to units $3 \mathrm{~A}$ and $3 \mathrm{C}$.

\section{Fauna and age}

Unit 3B has yielded poorly preserved brachiopods, corals and crinoids of Silurian age (GGU 83487, 83492-93).

Shales of unit 3F (GGU 83305-23) have yielded a graptolite fauna, including Bohemograptus bohemicus ?tenuis, Pristiograptus sp. and Saetograptus fritschi regarded by Berry et al. (1974) as indicative of a Ludlow, possibly Early Ludlow age. Other graptolites collected by Hurst \& Surlyk (1982, p. 70) from strata referred to units $3 E$ and $3 F$ support an Early to Middle Ludlow age for the upper part of the Hendrik $\emptyset$ section.

\section{Correlation}

Units 3A, 3C and 3G were referred to the Lauge Koch Land Formation of the Peary Land Group by Hurst \& Surlyk (1982. fig. 81). Unit 3B is not mentioned by these authors but is included in the outcrop area of the same formation. Units $3 \mathrm{E}$ and $3 \mathrm{~F}$ are equivalent to the Repulse Havn Member of the Wulff Land Formation as recognised by Hurst \& Surlyk on Hendrik $\emptyset$.

It should be noted that only a minor part of unit $3 \mathrm{D}$, comprising up to $25 \mathrm{~m}$ of predominantly conglomerate, is equivalent to the Hendrik $\varnothing$ Member of the Nordkronen Formation of Hurst \& Surlyk (1982). The main part of this sequence is included in the Lauge Koch Land Formation by these authors. The informal name Hendrik Conglomerate (Dawes, 1966) - unit 3D - was used for a thick conglomerate-bearing 'zone' in the sandstone turbidite succession and not, as inferred by Hurst \& Surlyk, in a restricted sense for conglomerate sensu stricto. There are several conglomerate-bearing intervals in this part of the clastic succession, and a second conglomerate horizon is also mentioned by Hurst \& Surlyk (1982, fig. 81). Conglomerate also outcrops on the islands in Sherard Osborn Fjord, e.g. Castle $\emptyset$, Reef $\varnothing$ and probably on Wedge $\varnothing$ and on Wulff Land.

\section{Korsgaard Bjerg, Nyeboe Land}

These sections (sections 4 and 5, fig. 3) are located on the north-eastern flank of Korsgaard Bjerg in central Nyeboe Land, overlooking the wide north-west trending valley, south-west of I. P. Ravn Højslette (fig. 9).

The sections are situated on the northern margin of a belt of carbonate build-ups and associated limestones that trend east-west across Nyeboe Land. Three rock units are recognised, two of which are, at least in part, facies equivalents.

\section{Description}

Korsgaard Bjerg is composed of a shallowly north dipping limestone sequence, at least $500 \mathrm{~m}$ thick. The lower approximately $300 \mathrm{~m}$ of strata examined (section 5) are composed of pale weathering, rather massive, grey limestone, frequently rich in stromatoporoids, with some beds of fine-grained platy limestones. Easterly outcrops are composed of a dark shale 
Fig. 9. Sketch map of north-eastern Korsgaard Bjerg, western Nyeboe Land, showing main lithologies at sections 4 and 5 . Shales of unit $4 \mathrm{~A}$ at location $\mathrm{G}$ have yielded Ludlow graptolites; section marked S (section 5) has yielded a shelly fauna of supposed Wenlock-Ludlow age.

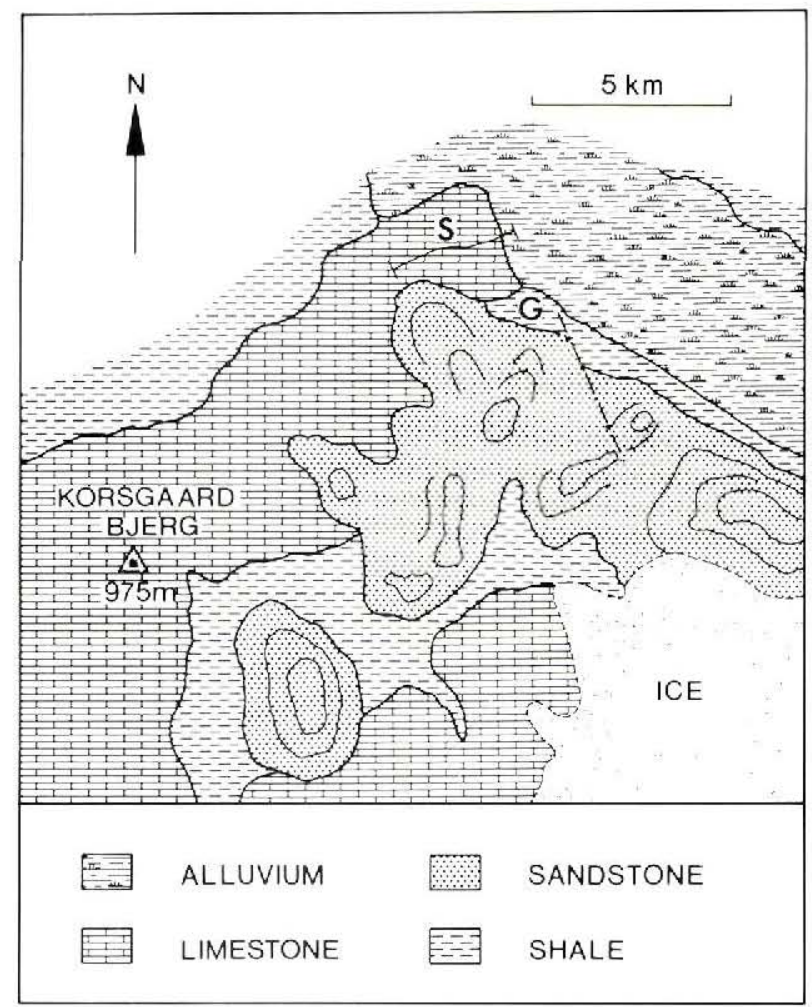

unit (4A) of black and dark grey shales with some laminated mudstone and grey siltstone, in which several thin beds of fossiliferous limestone - in places nodular - and limestone conglomerate occur. These beds appear to interdigitate with limestones of section 5 .

The shale unit is overlain by a thick sandstone unit (4B) that caps the valley side. On Korsgaard Bjerg this unit also disconformably overlies the limestones of section 5 (fig. 9), and several sandstone outliers of a once larger cover are preserved on adjacent summits to the south. Unit $4 \mathrm{~B}$ is composed of brown-yellow weathering, fine-grained calcareous sandstones, purplish at the base, greenish above, which contain some intercalated siltstone and shale beds in the uppermost part.

\section{Fauna and age}

Most of the fossil collection from unit 5 (GGU 82325-82400, 83401-14) was not located precisely within the approximately $300 \mathrm{~m}$ thick sequence of limestone forming the lower part of Korsgaard Bjerg. There are indications within the fauna of a range in age from Early to Late Silurian, but the lack of more specific locality information does not permit this assumption to be accurately tested.

Brachiopods, gastropods and trilobites dominate a fauna that contains stromatoporoids, Favosites sp., rugose corals, coiled and orthocone cephalopods and ostracods. Among the 
brachiopods, the smooth pentameroids Sapelnikovia and Harpidium are particularly prominent (P. M. Sheehan and J. M. Hurst, personal communication). Associated taxa include Howellella, Atrypella, Atrypa reticularis, Glassia(?) and Gypidula (A. J. Boucot and J. M. Hurst, personal communication). Gastropods include Eotomaria, Euomphalopterus, Cyclonema boreale, Salpingostoma(?) cf. S.(?) squamosa, S.(?) boreale, Offleya inexpectata, Liospira perdepressa, Poleumita and Phanerotrema(?). Lane (this report) records the trilobites Opoa adamsi, Meroperix ataphrus and Chiozoon cf. C. cowiei.

The presence of Sapelnikovia suggests a Late Llandovery to Wenlock age, but a number of North Greenland Silurian brachiopods show 'anomalous' ages (J. M. Hurst, personal communication). Harpidium may range into younger Ludlow strata, the presence of which also seem to be indicated by Atrypella.

Salpingostoma(?) squamosa is known from the Late Llandovery and Wenlock of Gotland (Lindström, 1884), while S.(?) boreale was described by Whiteaves (1906) from the Ekwan River Limestone in Canada of Late Llandovery age. Cyclonema boreale was described by Poulsen (1974) from the Late Llandovery of Washington Land, while the same author described Offleya inexpectata and Liospira perdepressa from strata of similar age on nearby Offley $\emptyset$.

Lane (this report) considers the trilobites to suggest an age near the Llandovery-Wenlock boundary, by comparison to faunas from Kronprins Christian Land to the east (Lane, 1972).

Unit 4A has yielded both a graptolite fauna (GGU 83415-17, 83433, 83435-47, 83449-53, $83456-57,83459-67,83470-71$ ) and a small shelly fauna (GGU 83434, 83448, 83454-5, 83458). The former includes Bohemograptus bohemograptus tenuis, Monoclimacis sp., Pristiograptus sp., Pristiograptus cf. P. dubius and Monograptus sp. (? M. colonus) regarded by Berry et al. (1974) to be of Ludlow, probably Early Ludlow age. The shelly fauna consists of pentameroid brachiopods, including Conchidium?, orthocone nautiloids and coral and crionoid remains.

The apparent lateral equivalence of unit $4 \mathrm{~A}$ with some of the limestones of unit 5 suggests that the latter is partly Ludlow in age.

\section{Correlation}

Limestones of section 5 can be referred to the Washington Land Group of Hurst (1980) and at least correspond to the Offley Island and Hauge Bjerge Formations. Section 4 can be referred to the Peary Land Group. Unit $4 \mathrm{~A}$, containing limestone beds, can be referred to the Lafayette Bugt Formation, although some lithologies are reminiscent of the Wulff Land Formation which, according to Hurst \& Surlyk (1982), forms large areas around I. P. Ravn Højslette. Unit 4B, the uppermost clastic strata, can be referred to the Lauge Koch Land Formation.

\section{Kayser Bjerg, Hall Land}

Sections 6 and 7 (fig. 3) are located on Kayser Bjerg in the eastern part of Hauge Bjerge, eastern Hall Land. The sections are located in the belt of carbonate build-ups and associated limestones that trends east-west across Hall Land and forms the prominent chain of hills known as the Hauge Bjerge.

Section 6 is a diagrammatic and composite representation of the general succession in the 
eastern part of Hauge Bjerge, from Kayser Bjerg to the Newman Bugt coast. The limestone section was mainly examined on the northern and eastern flanks of Kayser Bjerg. Section 7 is located in off-reefal strata on the northern flank of Kayser Bjerg, where a complex intertonguing and abrupt facies variations occur between the limestones of section 6 and the fine-grained strata of section 7 (fig. 10).

\section{Description}

Section 6 contains four main units. Unit $6 \mathrm{~A}$ is a flat-lying unit of light weathering limestones that are overlain by a thin, conspicuously dark weathering unit $(6 \mathrm{~B})$ of thinbedded platy limestones and shales. The overlying unit $(6 \mathrm{C})$ is a massive, biohermal unit with steep depositional dips. These three units are well exposed on the easternmost hill of the Hauge Bjerge at the Newman Bugt coast. Stratigraphically above these rocks, and forming the main massif of Kayser Bjerg is a thick unit (6D) of light weathering, rather massive and thick-bedded limestones, containing both biostromal and biohermal intervals and, near the top, lime mudstones.

Section 7 is a sequence of dark weathering platy limestones and shales, in places with limestone conglomerate and breccias, that interdigitate with the limestones of unit $6 \mathrm{C}$ and at least the lower part of unit $6 \mathrm{D}$.

\section{Fauna and age}

The lower and middle parts of unit 6D have yielded a rich fauna dominated by trilobites, brachiopods and corals (GGU 82632-78). A. J. Boucot and J. M. Hurst (personal communication) record a variety of brachiopods, including 'Atrypa reticularis', Leptaena 'rhomboidalis' and Atrypella phoca, the latter considered to indicate a Ludlow age. Associated fossils include the gastropods Poleumita cf. P. angulatum and Platyostoma; the former is a long ranging species in the Silurian of Gotland. Corals include Ketophyllum(?), Syringophyllum and Favosites; stromatoporoid, bryozoan, crinoid and ostracod samples also occur in the collection.

Among trilobites described by Lane (this report) are Ligiscus, Opsypharus, Kosovopeltis allaarti, Proetus s. 1. simus, Hedstroemia, Scotoharpes, Contracheirurus errator, Encrinurus, Calymene, Encrinurus (?Fragiscutum), Nonix sauroter, Sphaerexochus dimorphus and Dicranogmus aff. D. skinneri. Several of these taxa occur or can be compared with specimens from the late Wenlock of Canada (Perry \& Chatterton, 1977), suggesting a similar age for the Greenland sequence.

Section 7 has yielded both graptolitic and shelly faunas (GGU 82679-716), but these provide conflicting evidence as to age. A. J. Boucot and J. M. Hurst (personal communication) have identified the brachiopods Atrypella, Gracianella(?), Hedeina, Dicaelosia and 'Atrypa reticularis' considered indicative of a probable Ludlow age from platy limestones juxtaposed with similar graptolitiferous strata yielding Late Llandovery - Early Wenlock graptolites (W. B. N. Berry, personal communication). The graptolites include Retiolites geinitzianus, Monograptus flemingii, M. spiralis, Monoclimacis flumendosae, Cyrtograptus cf. C. sakmaricus, Pristiograptus sp. and Stomatograptus grandis? Lane (this report) records Sphaerexochus cf. S. dimorphus and poorly preserved encrinurids, the former suggesting a Wenlock-Ludlow age. 


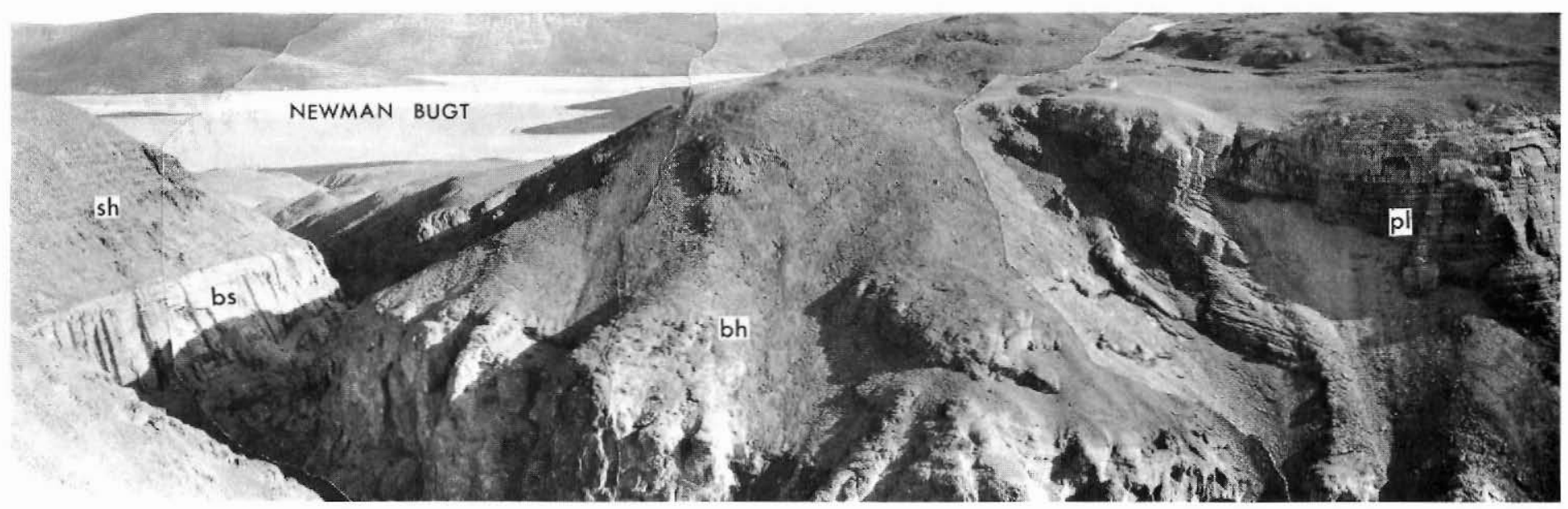

Fig. 10. Silurian facies relationships on north-eastern side of Kayser Bjerg, eastern Hauge Bjerge, Hall Land. Off-reefal shales (sh) and platy limestones (pl) of section 7 overlapping and grading into biohermal and biostromal limestones (bh and bs) of section 6. Height of cliffs is approximately $100 \mathrm{~m}$. A continuation of this reef complex is seen in coastal Nycboe Land across Newman Bugt.

V Fig. 11. Silurian facies relationships in the western Hauge Bjerge, Hall Land; sections 8, 9, 10 and 11. A = Kap Tyson, B, C and D = 'Sunmark Mountain'. A: South-western face of Kap Tyson seen from Offley $\varnothing$. Biostromal limestones (unit 10A, Offley Island Formation, OI) forming the lower part of the cliff is overlain by a prominent reef (unit 10B, Hauge Bjerge Formation, HB, Cape Tyson Member) that has steep depositional dips and passes into a much thinner platy limestone sequence (section 11, Lafayette Bugt Formation. LB). Summit of cape is about $740 \mathrm{~m}$ above sea-level. B: Western face of 'Sunmark Mountain' showing tripartite division of limestones of section 8 . Cliff height is about $550 \mathrm{~m}$. C: Off-reefal platy limestones and conglomerates of section 9 . south side of 'Sunmark Mountain'. Exposed section is about $200 \mathrm{~m}$. D: Graptolite shales of section 9, south-west 'Sunmark Mountain'. Exposed section is about $200 \mathrm{~m}$. 
A

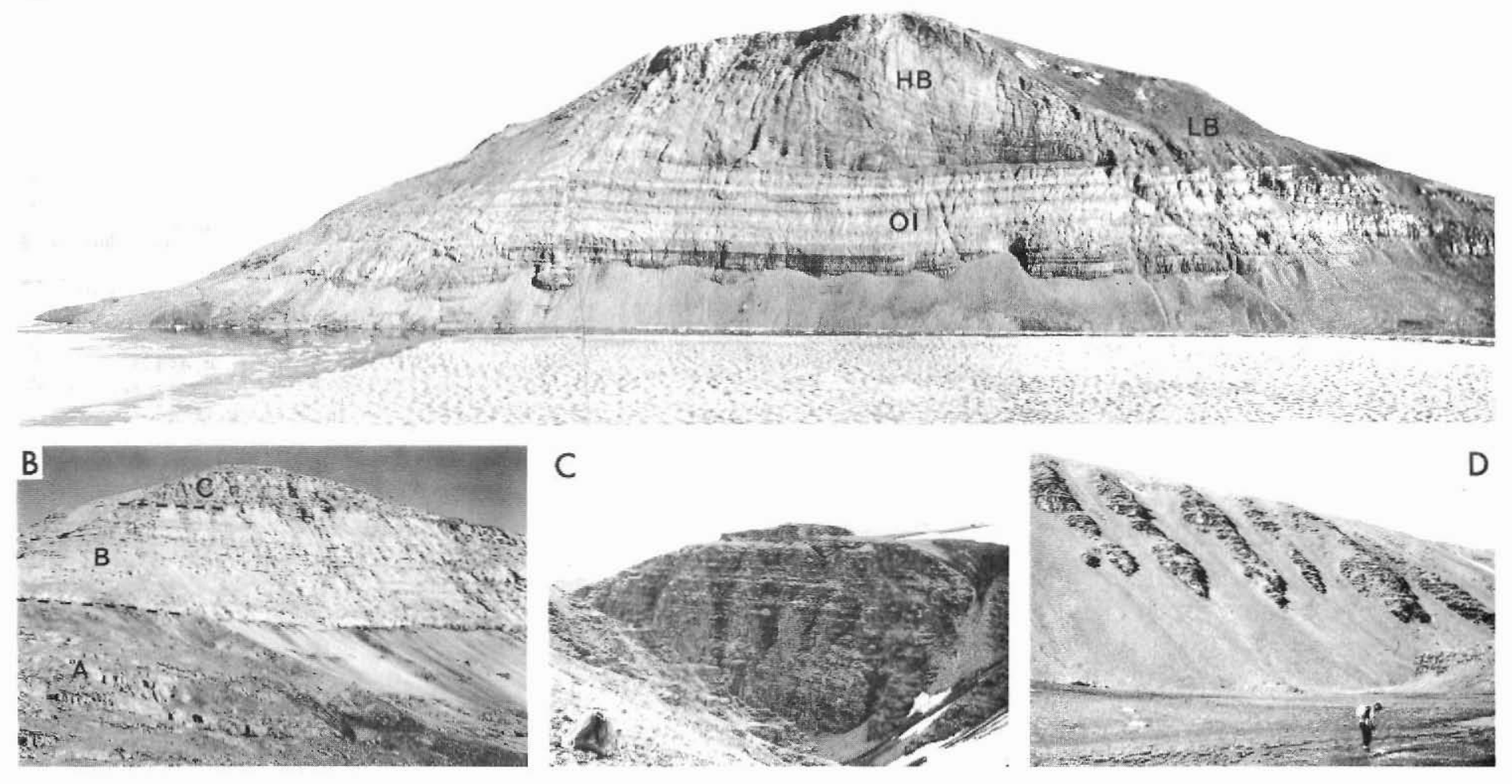


A rich conodont fauna from GGU 82687 includes Llandoverygnathus pennatus procerus, Apsidognathus cf. A. tuberculatus, Astrognathus tetractis, Ozarkodina hadra and Carniodus carnulus (R. J. Aldridge \& H. A. Armstrong, personal communication; Stouge \& Bagnoli, in press). This association is unusual in that L. pennatus procerus has previously always been recorded in association with Pterospathodus amorphognathoides; hence its presence usually indicates the amorphognathoides Zone. R. J. Aldridge (personal communication) regards the whole fauna as indicative of an age near to the Llandovery-Wenlock boundary.

It is not possible at this time to clarify the age discrepancies indicated by the above faunas but, in addition to facies or possible structural influences, it is suspected that the range of shelly faunal elements is anomalous, as suggested by J .M. Hurst above. However, as suggested elsewhere from the Hauge Bjerge in Hall Land (e.g. section 8) and in associated carbonates in Nyeboe Land (section 5), the platform and reef succession in this part of North Greenland most probably reaches into the Late Silurian (Ludlow).

\section{Correlation}

Section 6 can be referred to the Washington Land Group of Hurst (1980). The biohermal unit (6B) shows striking resemblance to the Kap Tyson Member of the Hauge Bjerge Formation as exposed at Kap Tyson (fig. 11A). However, the regional disposition of rock units suggests that this reef unit corresponds to the lower, rather than upper, level of carbonate build-ups that occurs in Washington Land and Hall Land (Hurst, 1980, p. 48). As such it is referable to the Bessels Fjord Formation. This formation, in its type locality in Washington Land, is characterised by the presence of a dark, recessive shale unit at its base; a possible correlative of unit $6 \mathrm{~B}$. However, in view of the intrinsic relationship between unit $6 \mathrm{~B}$ and the off-reefal facies south of the Hauge Bjerge, it seems preferable to refer unit $6 \mathrm{~B}$ to the Lafayette Bugt Formation of the Peary Land Group. This formation, according to Hurst (1980, p. 82), probably interdigitates with all formations of the Washington Land Group.

The upper part of the section forming the main massif of Kayser Bjerg (unit 6D) can be referred to the Offley Island and Hauge Bjerge Formations; its uppermost part may reach into the Kap Morton Formation. The lower unit (6A) may be in part equivalent to the Petermann Halvø Formation while its lowermost part at the Newman Bugt coast probably reaches down into the Aleqatsiaq Fjord Formation of the Morris Bugt Group.

The off-reefal strata of section 7 are referred to the Lafayette Bugt Formation that is regarded by Hurst \& Surlyk (1982) as representing the upper to lower slope environment. It should be noted that not all the strata composing the recessive fine-grained clastic terrain that flanks the Hauge Bjerge on the north are referable to that formation. Shales, mudstones, siltstones and fine-grained calcarenites which outcrop north of section 7 and form large areas to the west farther away from the reef complex, probably represent basin and basin margin deposits. As such, the strata may correlate with one or more of several formations of the Peary Land Group - the Wulff Land, the Lauge Koch Land and Chester Bjerg Formations.

\section{'Sunmark Mountain', Hall Land}

'Sunmark Mountain' is located in the western part of Hauge Bjerge, south-west Hall Land; two sections were examined (sections 8 and 9, fig. 3). The sections are located in the belt of carbonate build-ups and associated limestones forming the Hauge Bjerge. Section 8 is 
Fig. 12. Relationship between massive limestones $(\mathrm{ml})$ and off-reefal facies $(\mathrm{pl})$, southern side of 'Sunmark Mountain', western Hall Land. A: Interdigitation between massive limestones and shales and platy limestones; both facies at this locality have yielded brachiopod and conodont faunas; the brachiopods suggest the presence of strata of Ludlow age, the conodonts are considered to be of late Llandovery-Wenlock age. Some of the massive limestone outcrops may well be exotic representing reef talus derived from carbonate build-ups. Cliff height is approximately $150 \mathrm{~m}$. B: Exotic limestone boulder within deformed off-reefal shales. Block is about $15 \mathrm{~m}$ high. Background, poorly exposed shales of the Lafayette Bugt Formation.
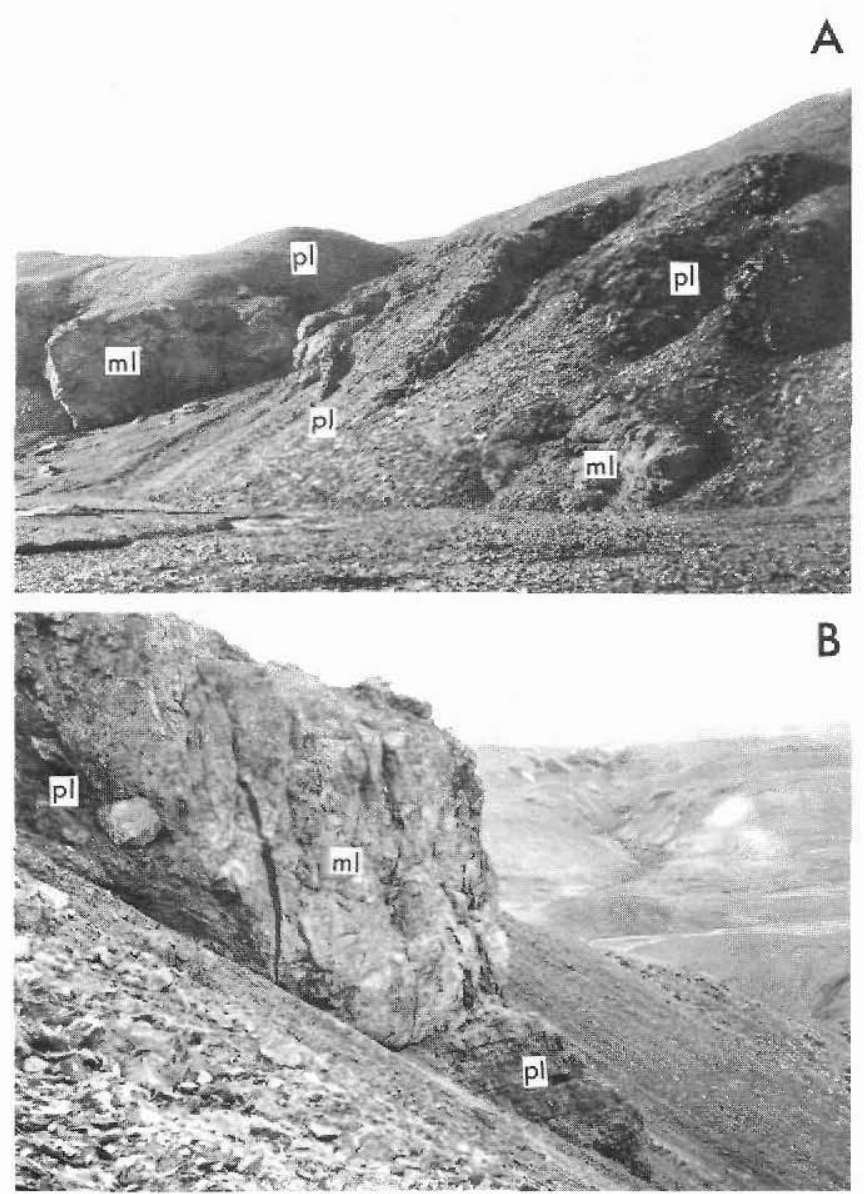

through the main carbonate sequence composing the main mountain massif which has the form of a broad basin structure. Section 9 is through the off-reefal calcarenites and argillaceous rocks that flank the carbonates on the south and which, at least in part, are their facies equivalents. Complex and abrupt interdigitating facies variations are common in the contact zone between the two sections.

\section{Description}

Section 8 is composed of three units (fig. 11B). Unit $8 \mathrm{~A}$ at the base is composed of thickbedded, light yellow weathering, massive biostromal and biohermal limestones, in places rich in stromatoporoids, with some conglomerates. This has a well-defined contact with the overlying unit $(8 \mathrm{~B})$ composed of thinner bedded, yellow weathering limestones, in places rich in coral and crinoid beds, and in which some conglomerate breccias and bioherms are developed. The upper unit $(8 \mathrm{C})$, gradational with the unit below, is a brown weathering sequence of limestones with some lime mudstones near the top. 
Section 9, situated on the south-west flanks of 'Sunmark Mountain' is composed of several hundred metres of thin-bedded platy limestones and calcareous siltstone and shales in which thin beds of limestone and limestone conglomerate and breccia occur (fig. 11C,D). These rocks have an interdigitating relationship with at least the lower part of the limestone section, units $8 \mathrm{~A}$ and $8 \mathrm{~B}$ (fig. 12A).

The lithology of this off-reefal succession varies with distance from the limestones of Hauge Bjerge. In the north, the section is dominated by platy limestones (fig. 11C) with frequent resedimented limestone breccia and conglomerate beds; to the south, the section is darker, thinner bedded and contains important intervals of graptolitic shales (fig. 11D). In places large isolated, sometimes rotated, limestone blocks occur within off-reefal shales. Crushing in the surrounding shales indicates that many of these blocks are exotic, presumably having been derived from the northern limestone massif (fig. 12B). Similar shalelimestone associations with exotic carbonate blocks up to about $50 \mathrm{~m}$ in diameter have been described from the Lafayette Bugt Formation of Nyeboe Land (Hurst \& Surlyk, 1982).

\section{Fauna and age}

In the area of interdigitation between sections 8 and 9 (fig. 12A), fossils were collected from massive limestones, some of which could be exotic blocks, and from the platy limestones and associated shales. Graptolites from the latter include Monograptus priodon, Monoclimacis cf. $M$. vomerinus gracilis, a cyrtograptid(?), a pristiograptid(?) and unidentified monograptids, considered by W. B. N. Berry (personal communication) to indicate a Late Llandovery - Wenlock age (GGU 82518-34).

The shelly fauna from the platy limestones (GGU 82535-44, 82552-55, 82563-65, 8256870 ) includes the brachiopods Janius, Skenidioides, Drummockina, Strophonella, 'Leptaena rhomboidalis', 'Atrypa reticularis', and Rhipidium(?), associated with Favosites, Lopohospira(?) and trilobite fragments. A. J. Boucot and J. M. Hurst (personal communication) consider the brachiopods to be of Ludlow age.

The fauna of the more massive limestones (GGU 82545-51, 82556-62, 82566-67) contains Favosites, Ketophyllum interuptum (Billings) Lambe, bryozoa, Harpidium, Gypidula and Atrypella prunum. Boucot and Hurst note that the presence of the latter suggests a Ludlow age, while the smooth pentamerid Harpidium ranges from the Late Llandovery into younger Silurian strata. A specimen of Holorhynchus(?) is of interest on account of its anomalous age; the genus is known from Late Ordovician - Early Silurian strata (P. M. Sheehan, personal commnuictaion).

R. J. Aldridge and H. A. Armstrong (personal communication) report Pseudobelodina(?) sp. nov. and Panderodus spp. from GGU 82543, Panderodus langkawiensis, $P$. sp., Walliserodus sp. and Dapsilodus sp. from GGU 82544, Oulodus(?) fluegeli, O. sp., $P$. aff. $P$. langkawiensis, $P$. cf. $P$. recurvatus, Pseudobelodina(?) sp. nov. and Walliserodus sp. from GGU 62565; all from the platy limestones. A massive limestone sample (GGU 82567) has yielded Ozarkodina cf. O. gulletensis, Oulodus(?) fluegeli, Panderodus aff. P. langkawiensis, Pseudobelodina(?) sp. nov. and Panderodus sp. Aldridge and Armstrong conclude that the conodont faunas themselves are not diagnostic of any particular conodont zone, but they include species widely recognised in the Late Llandovery - Wenlock of North Greenland. This suggestion is supported by Berry's determination of accompanying graptolites. 


\section{Correlation}

The carbonate sequence (section 8) can be referred to the Washington Land Group of Hurst (1980) and several formations known from Washington Land and westernmost Hall Land at Kap Tyson are probably represented. To the west of 'Sunmark Mountain' the main massif of the Hauge Bjerge is composed of a major carbonate build-up that is well exposed at Kap Tyson (fig. 11A). This build-up complex, composed of both core and flank deposits, is referred to the Cape Tyson Member of the Hauge Bjerge Formation (Hurst, 1980); both formation and member have the same type locality at Kap Tyson. Section 8 is composed of a well-bedded sequence of limestones and a precise correlation with the Kap Tyson section must await more field data. However, the main part of the section (unit $8 \mathrm{~B}$ and probably strata of unit 8A) may represent the flank deposits of a main carbonate build-up and as such are referable to the Hauge Bjerge Formation. The basal part of the section reaches down into the Offley Island Formation, and the uppermost part may correlate with the Cape Morton Formation.

All the off-reefal rocks (section 9) can be referred to the Lafayette Bugt Formation of the Peary Land Group of Hurst (1980).

\section{Kap Tyson, Hall Land}

Sections 10 and 11 (fig. 3) are located on the steep cliffs of Kap Tyson in south-western Hall Land (fig. 11A). The cliffs were traversed on the southern side from the westerly flowing river to near the summit. The cape exposes a spectacular section through a major carbonate build-up and steep depositional dips occur on the flanks of the reef core. About $750 \mathrm{~m}$ of strata are exposed, referable to three main units, with facies and thickness variation from about $350 \mathrm{~m}$ of limestones in the reef core (section 10, unit 10B) to a little more than $100 \mathrm{~m}$ of off-reefal rocks at the base of the southern flank (section 11, fig. 3). The underlying unit (10A) is a conspicuously banded sequence of mainly biostromal limestones with conglomerates and minor bioherms.

The highly fossiliferous limestones at Kap Tyson and on the adjacent small island, Offley $\varnothing$, were first examined by the Hall and Nares expeditions (Etheridge, 1878; Feilden \& De Rance, 1878; Bessels, 1879). The localities became the type areas of the Offley Island and Cape Tyson Formations of Koch (1929). Detailed biostratigraphic studies have been carried out by Norford (1972) and Hurst (1980), and the reader is referred to these papers for detailed stratigraphic description.

\section{Fauna and age}

Silurian faunas from Kap Tyson and the nearby Offley $\emptyset$ are described and discussed by Etheridge (1878), Poulsen (1934, 1941, 1943, 1974), Norford (1972), McLean (1977) and Peel (1979). Hurst (1980) has reviewed these earlier descriptions and provided additional biostratigraphic information.

McLean (1977) described 13 species of rugose corals from collections made at Kap Tyson and Offley $\emptyset$ by B. S. Norford (Geological Survey of Canada) under 'Operation Grant Land'. Characteristic Late Llandovery genera included Crassilasma and Pseudophaulactis, associated with species of Craterophyllum, Ptychophyllum, Amplexoides, Hedstroemophyl- 
lum, Kenophyllum(?). Kodonphyllum(?) and Cystilasma(?). McLean also reviewed earlier descriptions by Poulsen (1941).

Among gastropods collected by Norford from Offley $\emptyset$ are Murchisonia (?M.) latifasciata Etheridge, Michelia(?) persimilis Poulsen, Lophospira(?) and Grantlandispira (see Peel, this report). Several specimens, mainly indeterminate, also occur from Kap Tyson.

In 1965, fossils were collected from the middle and upper parts of unit $10 \mathrm{~A}$. The fauna (GGU 82572-82630) is dominated by stromatoporoids, tabulate corals (mainly species of Favosites and a Propora(?)) and undetermined rugosans. Brachiopods include specimens of a smooth pentameroid, a rhynchonellid, a rostrospiroid and Dolerorthis flabellites (A. J. Boucot, personal communication). Lane (this report) illustrates a poorly preserved encrinurine trilobite, while Peel (this report) describes a new gastropod, Grantlandispira, related to Pycnomphalus. Available fossils are from the Offley Island Formation which Hurst (1980), in agreement with earlier workers, considered to be of Late Llandovery age. The current collections do not challenge this opinion.

A single collection of graptolites (GGU 82571) from platy limestones of section 11 interdigitating with the limestones of unit 10A contains Monograptus of $M$. priodon type, Monoclimacis sp. and Pristiograptus sp. which W. B. N. Berry (personal communication) considered to be of general Late Llandovery - Wenlock age.

\section{Correlation}

Unit $10 \mathrm{~A}$ of biostromal limestones and unit 10B, the carbonate build-up sequence, are reference and type sections of the Offley Island and Hauge Bjerge Formation (Cape Tyson Member), respectively, of the Washington Land Group of Hurst (1980) (fig. 11A). Section 11 of platy limestones and shales is part of the Lafayette Bugt Formation of the Peary Land Group (see Hurst, 1980, fig. 42).

\section{Newman Bugt, Nyeboe Land}

This section (12, fig. 3 ) is located in south-western Nyeboe Land, in the wide east-west valley that reaches to the southern part of Newman Bugt, south-west of Korsgaard Bjerg (see fig. 1).

The valley sides are composed of shallow northerly dipping, medium-bedded, cliffforming limestones that are fairly monotonous in general appearance, without well-marked divisions. In the traversed section on the southern side of the valley, four units were recognised. Some of the fossils were collected on the northern side of the valley.

\section{Description}

The lower half of the section (12A) is composed of pale weathering, grey limestones, variously mottled, veined and in places brecciated. Some beds contain abundant crinoids, while orthocone nautiloids are conspicuous in others. White and pale grey, pinkish sugary limestone beds occur in the middle part. The overlying unit (12B) is made up of grey to brownish weathering limestones that are commonly rich in pentamerid brachiopods. These are overlain by dark to light grey, mottled and in places brecciated limestone (12C). The upper part of the section (unit 12D) is composed of grey limestone and lime mudstone. 


\section{Fauna and age}

The upper part of unit 12A (GGU 82109-29) contains a fauna dominated by brachiopods, associated with Megalomphala, Kionoceras, the trilobites Ligiscus cf. L. arcanus and Chiozoon (see Lane, this report), Favosites and stromatoporoids. The brachiopods include stropheodontids, dubarids, atrypaceans and pentamerids, including Harpidium(?), indicative of a Late Llandovery or younger Silurian age (A. J. Boucot and J. M. Hurst, personal communication). Lane (this report) considers the trilobites to be of Late Llandovery Wenlock age. The single weathered specimen of Megalomphala is reminiscent of the Salpingostoma septentrionale of Poulsen (1974), described from Kap Morton in Washington Land.

Unit 12B (GGU 82130-32, 82137-42) also contains Harpidium, together with a species of Favosites, apparently also present in unit 10A (Offley Island Formation) at Kap Tyson.

Unit 12C (GGU 82133-36) contains pentameroid brachiopods, Favosites and a specimen of the tabulate Propora(?) also recorded from unit 10A.

Unit 12D (GGU 82143-47) contains stromatoporoids and two specimens of Favosites; one of these is apparently the same species noted from unit 12B above.

The fauna of section 12 as a whole suggests a probable Late Llandovery age which is supported by the occurrence of several species known from strata of this age at Kap Tyson.

\section{Correlation}

The upper part of the limestone section (units 12B, C and D) can undoubtedly be referred to the Washington Land Group of Hurst (1980) and at least the Offley Island Formation is represented. The lower unit (13A) probably corresponds to more than one formation, with the lower part reaching down into the Morris Bugt Group. The age of the lower part of the unit is unknown; no fossils were collected, but some lithologies are similar to those of the Aleqatsiaq Fjord Formation of Hurst (1980).

\section{Store Canyon, Nyeboe Land}

Sections 13 and 14 (fig. 3) are located in Store Canyon in southern Nyeboe Land, where a thick succession of carbonates are well exposed in the steep sides of the valley (fig. 13). The strata have a northerly dip of a few degrees; in the south both Ordovician and Silurian strata outcrop, whereas in the northernmost parts of the valley only Silurian rocks are exposed.

Two sections were visited. Section 13, in the north, on the eastern side of the valley, was examined through the entire valley cliff (fig. 13B). Section 14, in the south, was only briefly traversed on the western side of the valley; it is illustrated here by a view of the opposite side of the valley (fig. 13C).

\section{Description}

In section 13, the northernmost section, five units were recognised (fig. 13B). The lowermost strata, exposed above the heavy Quaternary fill of the valley floor, are dark weathering, massive, dark grey to bluish grey, intensely mottled limestone and dolomitic limestone, in places with conspicuous orthocone nautiloids (unit 13A). This passes into a 

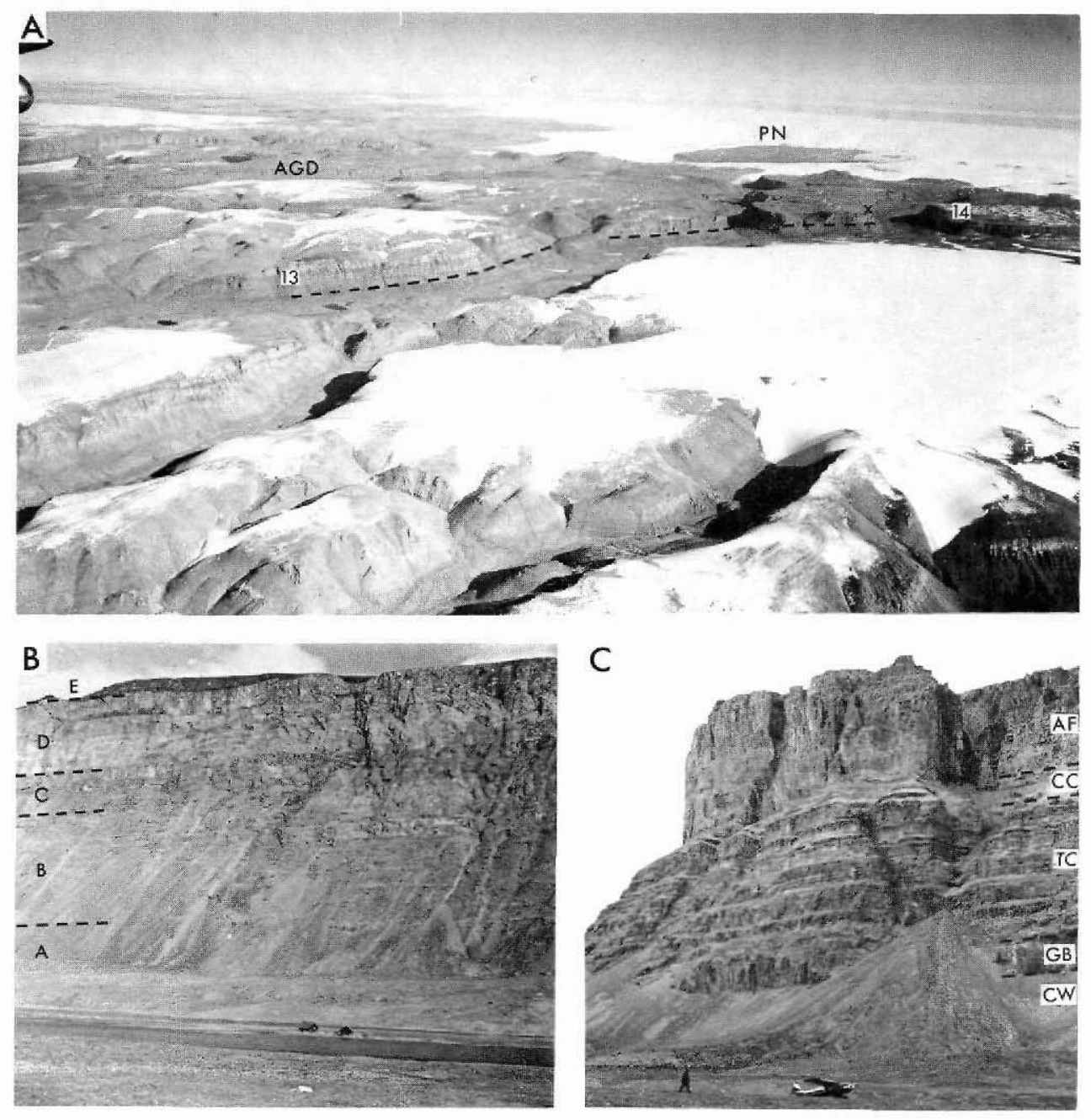

Fig. 13. Ordovician-Silurian stratigraphy of Store Canyon, southern Nyeboe Land. A: Easterly view over Store Canyon towards Porsild Nunatak (PN) and Alma Glück Dal (AGD) showing the shallow northerly dipping carbonate strata. Locations of sections 13 and 14 , and the lower boundary of the Aleqatsiaq Fjord Formation, are indicated. Aerial photograph $546 \mathrm{~F}-\emptyset$, nr. 11570, copyright Geodætisk Institut, Denmark, published with permission A.649/78. B: Succession of section 13, eastern side of canyon. Cliff height is approximately $800 \mathrm{~m}$. C: Succession at section 14, on eastern side of canyon - location marked $\mathrm{X}$ in aerial view above. Letters refer to suggested formational designation, $\mathrm{CW}=$ Cape Webster Frm., GB = Gonioceras Bay Frm., TC = Troedsson Cliff Frm., CC = Cape Calhoun Frm., AF = Aleqatsiaq Fjord Frm. Cliff height is approximately $800 \mathrm{~m}$. 
thicker unit (13B) of medium-bedded to massive limestone which is dark and mottled at the base, but varies upwards to include pale weathering, grey limestones with only slight mottling. Some beds of calcareous shale occur in the middle part. The overlying dark weathering unit $(13 \mathrm{C})$ is composed of dark grey fine-grained limestone with some beds rich in pentamerid brachiopods. This is followed by pale weathering, rather massive limestones that in places are reefoid and rich in corals and stromatoporoids (unit 13D). To the north several carbonate build-ups are developed in the upper part of this unit. The youngest strata exposed (unit 13E), forming the top of the cliffs, are conspicuously dark coloured, thinbedded, highly fossiliferous, bituminous limestone and calcareous shale with some limestone conglomerate and pale limestone beds.

In the southern part of Store Canyon (section 14), a bipartite division of the valley cliffs is apparent (fig. 13C). The lower unit (14A) is a well-bedded sequence of generally dark limestone and dolomite that contains several recessive intervals of thin-bedded limestone and shale. One of these recessive intervals occurs at the top of the unit. The upper unit (14B) is a massive cliff-forming unit composed of light weathering, variously mottled, thick-bedded limestone.

\section{Fauna and age}

Unit 14A has yielded the stratigraphically oldest fauna known from sections 13 and 14, namely Labyrinthites (L.) chidlensis Lambe, Receptaculites, Maclurites, a strophomenacean brachiopod and fragmentary illaenomorph trilobites (GGU 82312-22). All these forms occur within the lower and middle parts of the Troedsson Cliff Formation of the Morris Bugt Group in Washington Land, and suggest a late Middle Ordovician age. The fauna also contains a favositid not characteristic of the interval, although Palaeofavosites does occur at the top of the formation in Washington Land and in the overlying Cape Calhoun Formation. The fauna from unit $14 \mathrm{~A}$ was not collected from a single bed, which may explain this anomalous association.

Unit 13A (GGU 82151-77) contains Salpingostoma, a Cymbularia(?) also known from unit 1A at Kap Ammen, Maclurites, Trochonema, Armenoceras, Huronia, rhynchonellid brachiopods and rugose corals. The latter have been examined by B. E. Neuman (personal communication) who reports Dalmanophyllum, Bighornia and Streptelasma, considered to be of latest Ordovician or earliest Silurian age. The rugose fauna is not comparable to that known from Kap Ammen. Other faunal elements appear to preclude a Silurian age, and the fauna of unit $13 \mathrm{~A}$ is thus considered to be of Late Ordovician age.

Unit 13B (GGU 82178-94) has yielded a fauna of pentameroid brachiopods associated with an indeterminate cephalopod and a single fragmentary specimen of Salpingostoma. The pentameroids include Virgiana and Proconchidium(?) considered to be Early-Middle Llandovery in age by P. M. Sheehan and J. M. Hurst (personal communication). The former species is also known from unit $1 \mathrm{C}$ at Kap Ammen.

Unit 13C (GGU 82195-200) contains pentameroid brachiopods associated with $\mathrm{Pal}$ aeofavosites groenlandicus Poulsen, a species otherwise known from Offley $\emptyset$. The unit is considered to be of probable Early Silurian age.

Unit 13D has yielded a poor fauna (GGU 82205-10) of smooth brachiopods, stromatoporoids, crinoids, bryozoans and Favosites.

The fauna of unit 13E (GGU 82211-311) is dominated by rugose and tabulate corals, and 
brachiopods. The latter include 'Dolerorthis flabellites', 'Leptaena rhomboidalis', rhynchonellids, stropheodeontids and a possible Coelospira or Gracianella which A. J. Boucot (personal communication) considered to be probably no older than Early Wenlock. J. M. Hurst (personal communication) has recognised a similar form, however, in probable Late Llandovery strata from Kap Ammen (units 1D,E). Tabulates from unit 13E include Favosites spp., Heliolites and Aulopora; rugosans and bryozoans are not determined. Lane (this report) records indeterminate encrinurids and a Bumastus sp.

\section{Correlation}

The stratigraphic relationship between sections 13 and 14 is illustrated in fig. 13A. The strata of section 14 can be referred to the Morris Bugt Group defined by Peel \& Hurst (1980) for the cliff-forming carbonates that span the Ordovician-Silurian boundary in Washington Land. The lower unit (14A) almost certainly corresponds to the stratigraphic interval covered by the Troedsson Cliff and Cape Calhoun Formations, while the base of the section reaches down to the cliff-forming Gonioceras Bay Formation, the basal unit of the Morris Bugt Group, and possibly the recessive Cape Webster Formation (fig. 13C). The upper unit (14B) and units 13A, 13B and possibly 13C of the northern section can be referred to the Aleqatsiaq Fjord Formation, the uppermost formation of the Morris Bugt Group. Unit 13D, containing carbonate build-ups in the upper part, may correspond to the Petermann Fjord and Bessels Fjord Formations of the Washington Land Group (Hurst, 1980). Unit 13E represents a new formation; it is not known elsewhere in North Greenland, but can be referred to the Washington Land Group.

Acknowledgements. The field work in Greenland was carried out by one of us (PRD) in company with the late Dr. Jan H. Allaart in 1965 and S. Skytte in 1966; the former was responsible for collecting many of the data and fossils from Hall Land. Thanks are directed to R. L. Christie, Geological Survey of Canada, leader of Operation Grant Land, for the organisation of the field logistics from base camps in Ellesmere Island, and for help and encouragement in the preparation of this account. Fixed-wing pilots, J. Strickland, S. Standisch and S. McKenzie, Bradley Air Services, are thanked for their endeavours in landing fly camps as close as possible to chosen sections and for good companionship in the field.

We are grateful to the following for fossil identifications included in this report: $R$. J. Aldridge and $H$. A. Armstrong, University of Nottingham (H. A. A., now University of Newcastle-upon-Tyne), W. B. N. Berry, University of California, Berkeley, A. J. Boucot, Oregon State University, J. M. Hurst, Geological Survey of Greenland (now, British Petroleum, London), V. Poulsen, University of Copenhagen, B. E. Neumann, University of Bergen, P. M. Sheehan, Milwaukee Public Museum, and S. Turner, Queensland Museum. Thanks are also directed to J. M. Hurst for valuable discussions on Silurian stratigraphy and for the use of unpublished information.

Finally, we thank E. Glendal for technical assistance in the preparation of the manuscript.

\section{References}

Allaart, J. H. 1965: The Lower Paleozoic sediments of Hall Land, North Greenland. Unpubl. intern. GGU rep., $11 \mathrm{pp}$.

Allaart, J. H. 1966: Hall Land, Northwest Greenland. Pap. geol. Surv. Can. 66-1, 4 only.

Armstrong, H. A. \& Dorning, K. J. this report: Silurian palynomorphs from the Chester Bjerg Formation, Hall Land, western North Greenland. Rapp. Grønlands geol. Unders. 121, 97-103. 
Beaumont, L. A. 1877: Report of sledge journey by Lieut. L. A. Beaumont, between 6th April and 15th August. In Nares, G. S. Journals and Proceedings of the Arctic Expedition 1875-6, under the command of Captain Sir George S. Nares, R.N., K.C.B., 341-358. London: Parliamentary Paper C-1636.

Bendix-Almgreen, S. E. 1976: Palaeovertebrate faunas of Greenland. In Escher, A. \& Watt, W. S. (edit.) Geology of Greenland, 534-573. Copenhagen: Geol. Surv. Greenland.

Bendix-Almgreen, S. E. \& Peel, J. S. 1974: Early Devonian vertebrates from Hall Land, North Greenland. Rapp. Grønlands geol. Unders. 65, 13-16.

Berry, W. B. N., Boucot, A. J., Dawes, P. R. \& Peel, J. S. 1974: Late Silurian and early Devonian graptolites from North Greenland. Rapp. Grønlands geol. Unders. 65, 11-13.

Bessels, E. 1879: Die amerikanische Nordpol-Expedition. Leipzig: Von Wilhelm Engelmann, 647 pp.

Boucot, A. J. \& Hurst, J. M. 1979: Silurian biogeography: revision of the North Atlantic Realm in the Llandovery. Rapp. Grønlands geol. Unders. 91, 57-60.

Davies, W. E., Needleman, S. M. \& Klick, D. W. 1959: Report on Operation Groundhog (1958) North Greenland. Investigations of ice-free sites for aircraft landings, Polaris Promontory, North Greenland. U.S.A.F. Cambridge Res. Center, Bedford, 45 pp.

Davis, C. H. 1876: Narrative of the North Polar Expedition U.S. Ship Polaris, Captain Charles Francis Hall commanding. Washington: Gov. Print. Off., 696 pp.

Dawes, P. R. 1966: Lower Palaeozoic geology of the western part of the North Greenland fold belt. Rapp. Grønlands geol. Unders. 11, 11-15.

Dawes, P. R. 1971: The North Greenland fold belt and environs. Bull. geol. Soc. Denmark 20, 197-239.

Dawes, P. R. 1976: Precambrian to Tertiary of northern Greenland. In Escher, A. \& Watt, W. S. (edit.) Geology of Greenland, 248-303. Copenhagen: Geol. Surv. Greenland.

Dawes, P. R. 1982: The Nyeboe Land fault zone: a major dislocation on the Greenland coast along northern Nares Strait. In Dawes, P. R. \& Kerr, J. W. (edit.) Nares Strait and the drift of Greenland: a conflict in plate tectonics. Meddr Grønland, Geosci. 8, 177-192.

Dawes, P. R. 1984: Programme NordGrøn (PNG) 1983-1985: regional mapping and geological studies in western and central North Greenland. Rapp. Grønlands geol. Unders. 120, 18-24.

Dawes, P. R. this report: Operation Grant Land 1965-1966; a geological exploration programme in Ellesmere Island and North Greenland. Rapp. Gronlands geol. Unders. 121, 5-17.

Dawes, P. R. \& Haller, J. 1979: Historical aspects in the geological investigation of northern Greenland. Part 1: New maps and photographs from the 2nd Thule Expedition 1916-1918 and the Bicentenary Jubilee Expedition 1920-1923. Meddr Grønland 200(4), 38 pp.

Etheridge, R. 1878: Palæontology of the coasts of the Arctic lands visited by the late British Expedition under Captain Sir George Nares, R. N., K.C.B., F.R.S. Q. Jl geol.Soc. Lond. 34, 568-636.

Feilden, H. W. \& De Rance, C. E. 1878: Geology of the coasts of the Arctic lands visited by the late British Expedition under Captain Sir George Nares, R. N., K.C.B., F.R.S. Q. Jl geol. Soc. Lond. 34, 556-567.

Hurst, J. M. 1980: Silurian stratigraphy and facies distribution in Washington Land and western Hall Land, North Greenland. Bull. Grønlands geol. Unders. 138, 95 pp.

Hurst, J. M. \& Kerr, J. W. 1982: Upper Ordovician to Silurian facies patterns in eastern Ellesmere Island and western North Greenland and their bearing on the Nares Strait lineament. $\ln$ Dawes, P. R. \& Kerr, J. W. (edit.) Nares Strait and the drift of Greenland: a conflict in plate tectonics. Meddr Grønland, Geosci. 8, 137-145.

Hurst, J. M. \& Peel, J. S. 1979: Late Proterozoic(?) to Silurian stratigraphy of southern Wulff Land, North Greenland. Rapp. Grønlands geol. Unders. 91, 37-56.

Hurst, J. M. \& Surlyk, F. 1982: Stratigraphy of the Silurian turbid te sequence of North Greenland. Bull. Grønlands geol. Unders. 145, $121 \mathrm{pp.}$

Ineson, J. R. \& Peel, J. S. 1980: Cambrian stratigraphy in Peary Land, eastern North Greenland. Rapp. Grønlands geol. Unders. 99, 33-42. 
Koch, L. 1920: Stratigraphy of Northwest Greenland. Meddr dansk geol. Foren. 5(17), 78 pp.

Koch, L. 1929: Stratigraphy of Greenland. Meddr Grønland 73,2(2), 205-320.

Lane, P. D. 1972: New trilobites from the Silurian of north-east Greenland, with a note on trilobite faunas in pure limestones. Palaeontology 15, 336-364.

Lane, P. D. this report: Silurian trilobites from Hall Land and Nyeboe Land, western North Greenland. Rapp. Grønlands geol. Unders. 121, 53-75.

Lane, P. D., Dawes, P. R. \& Peel, J. S. 1980: A new Silurian Hemiarges (Trilobita) from North Greenland and the question of the Polaris Harbour Formation. Rapp. Gronlands geol. Unders. 101, $45-53$.

Lindström, G. 1884: On the Silurian Gastropoda and Pteropoda of Gotland. Kungl. Svenska Vetenskaps Akad. Handl. 19(6), $250 \mathrm{pp}$.

Major, H. \& Winsnes, T. S. 1955: Cambrian and Ordovician fossils from Sørkapp Land, Spitsbergen. Skrifter Norsk Polarinstit. 106, 47 pp.

McLean, R. A. 1977: Early Silurian (Late Llandovery) rugose corals from western North Greenland. Bull. Grønlands geol. Unders. 121, $46 \mathrm{pp}$.

Norford, B. S. 1972: Silurian stratigraphic sections at Kap Tyson, Offley $\emptyset$ and Kap Schuchert, northwestern Greenland. Meddr Grønland 195(2), $40 \mathrm{pp}$.

Palmer, A. R. \& Peel, J. S. 1979: New Cambrian faunas from Peary Land, eastern North Greenland. Rapp. Grønlands geol. Unders. 91, 29-36.

Peel, J. S. 1974: Lower Cambrian fossils from Nyeboe Land, North Greenland fold belt. Rapp. Grønlands geol. Unders. 65, 17 only.

Peel, J. S. 1975: Beatricea from the Ordovician of Hall Land, North Greenland. Rapp. Grønlands geol. Unders. 75, 31-34.

Peel, J. S. 1979: Serrodiscus from northern Nyeboe Land, North Greenland. Rapp. Grønlands geol. Unders. 91, 116 only.

Peel, J. S. 1980: Cambrian and Ordovician geology of Warming Land and southern Wulff Land, central North Greenland. Rapp. Gronlands geol. Unders. 101, 55-60.

Peel, J. S. 1982: The Lower Paleozoic of Greenland. In Embry, A. F. \& Balkwill, H. R. (edit.) Arctic Geology and Geophysics. Mem. Can. Soc. Petrol. Geol. 8, 309-330.

Peel, J. S. this report: Autecology and systematics of a new Silurian anomphalid gastropod from western North Greenland. Rapp. Grønlands geol. Unders. 121, 77-87.

Peel, J. S. \& Christie, R. L. 1982: Cambrian-Ordovician platform stratigraphy: correlations around Kane Basin. In Dawes, P. R. \& Kerr, J. W. (edit.) Nares Strait and the drift of Greenland: a conflict in plate tectonics. Meddr Grønland, Geosci. 8, 117-135.

Peel, J. S. \& Hurst, J. M. 1980: Late Ordovician and early Silurian stratigraphy of Washington Land, western North Greenland. Rapp. Grønlands geol. Unders. 100, 18-24.

Peel, J. S. \& Larsen, N. H. this report: Hadimopanella apicata from the Lower Cambrian of western North Greenland. Rapp. Gronlands geol. Unders. 121, 89-96.

Peel, J. S. \& Yochelson, E. L. 1976: Two new gastropod genera from the Lower Silurian of the Oslo region, Norway. Norsk Geol. Tidsskr. 56, 15-27.

Perry, D. G. \& Chatterton, B. D. E. 1977: Silurian (Wenlockian) trilobites from Baillie-Hamilton Island, Canadian Arctic Archipelago. Can. J. Earth Sci. 14, 285-317.

Poulsen, C. 1934: The Silurian faunas of North Greenland. I. The fauna of the Cape Schuchert Formation. Meddr Grønland 72,2(1), 46 pp.

Poulsen, C. 1941: The Silurian faunas of North Greenland. II. The fauna of the Offley Island Formation. Part I Coelenterata. Meddr Gronland 72,2(2), 28 pp.

Poulsen, C. 1943: The Silurian faunas of North Greenland. II. The fauna of the Offley Island Formation. Part II Brachiopoda. Meddr Grønland 72,2(3), $60 \mathrm{pp}$.

Poulsen, C. 1974: Silurian Pelecypoda, Monoplacophora, and Gastropoda from the reefy facies of the Offley Island Formation of Washington Land and Offley Island (Northwest Greenland). Biol. Skr. Dan. Vid. Selsk. 20(7), 14 pp. 
Poulsen, V. 1969: An Atlantic Middle Cambrian fauna from North Greenland. Lethaia 2, 1-14.

Robison, R. A. 1984: Cambrian Agnostida from North America and Greenland; Part I, Ptychagnostidae. Paleont. contr. Kansas Univ. 109, 59 pp.

Stouge, S. \& Bagnoli, G. in press: An Upper Llandovery conodont fauna from eastern Hall Land, northern Greenland. Bull. Soc. Paleont. Italia.

Surlyk, F., Hurst, J. M. \& Bjerreskov, M. 1980: First age-diagnostic fossils from the central part of the North Greenland foldbelt. Nature, Lond. 286, 800-803.

Troedsson, G. T. 1926: On the Middle and Upper Ordovician faunas of northern Greenland. I. Cephalopods. Meddr Grønland 71(1), 1-157.

Troedsson, G. T. 1928: On the Middle and Upper Ordovician faunas of northern Greenland. II. Meddr Grønland 72,1(1), 197 pp.

Whiteaves, J. F. 1906: The fossils of the Silurian (Upper Silurian) rocks of Keewatin, Manitoba, the northeastern shore of Lake Winnipegosis and the lower Saskatchewan River. Palcozoic Fossils 3, 243-298. Geol. Surv. Canada.

Wrona, R. 1982: Early Cambrian phosphatic microfossils from southern Spitsbergen (Hornsund Region). Palaeont. Polonica 43, 9-16.

Note added in proof:

Field work in summer 1984 has shown that the contact between the Cambro-Ordovician strata composing the northern coast of Nyeboe Land and the Silurian turbidites to the south (units 1-2 and 3 respectively on fig. 4) is essentially sedimentary. Steeply-inclined strike faults along this contact, previously interpreted to form a major dislocation along the southern limb of the Wulff Land anticline (Hand Bugt fault of the Nyeboe Land fault zone of Dawes, 1982), are now interpreted as local thrusts that have not radically disturbed the regional disposition of rock units (A. K. Higgins and N. J. Soper, personal communication). 